\title{
Neglected elements: What we should cover more of in international business research
}

\author{
Ilgaz Arikan ${ }^{1}$ and \\ Oded Shenkar ${ }^{2}$ \\ ${ }^{1}$ Department of Management and Information
Systems, College of Business Administration, Kent
State University, A413 Terrace Drive, Kent,
OH 44242, USA; ${ }^{2}$ Ford Motor Company Chair in
Global Business Management, Department of
Management and Human Resources, Fisher
College of Business, The Ohio State University,
2100 Neil Avenue, Columbus, OH 43210, USA
}

Correspondence:

I Arikan, Department of Management and Information Systems, College of Business

Administration, Kent State University, A413

Terrace Drive, Kent, OH 44242, USA

e-mail: iarikan@kent.edu

\begin{abstract}
The international business (IB) field is maturing and developing conceptual frameworks, dedicated applications, and precise tools. In the course of this progression, the field has started to break away from its disciplinary roots, establishing parsimonious models using finely tuned but confined approaches. While fruitful in solidifying the sovereignty of the field, this progression comes at the expense of detecting and building on major undercurrents that define the rich IB context. We return here to the foundations of IB research to identify neglected elements and offer suggestions as to why they should and how they can be incorporated to deepen and strengthen the field's reach and impact. We discuss the neglected elements in five clusters, namely audiences and actors (intended readers and key players), locations (research sites), environmental layers (contextual tiers), history (prior paths), and interactions (among players and elements). We highlight how those clusters taken together on their conceptual underpinnings and empirical proxies will support IB research, first by way of producing a virtuous cycle of theory-to-issue research to open the perennial "black box"; and second by enabling eclectic, interdisciplinary research and retrospective investigation using a multifaceted lens.
\end{abstract}

Journal of International Business Studies (2022) 53, I484-1507.

https://doi.org/ | 0. 1057/s4 I 267-02 I-00472-9

Keywords: MNEs; international political economy; history in international business; conflict and animosity; incorporating country variables; geography

\section{INTRODUCTION}

In the half century of its formal life, the international business (IB) field has made important and valuable inroads, advancing knowledge on trade, foreign investment, and a variety of topics of interest to scholars and practitioners of comparative and, in particular, cross-border business. As in other areas, the process of field evolution in IB has been accompanied by the crystallization of traditions and routines that, while useful as guideposts, have also been confining in that they may have crowded out or veiled other elements of interest, be they audiences, actors, or topics of interest. Our theme is identifying neglected elements and offering suggestions as to why they should and how they can be incorporated to enrich and strengthen the field.

To identify neglected elements, we return to the foundations upon which IB was built, drawing from anthropology, sociology, economics, and political science, among other scholarly fields, as
Received: 13 May 2020

Revised: 8 May 2021

Accepted: 12 July 2021

Online publication date: 28 October 2021 
well as interdisciplinary research across those fields. These sources and in particular the way in which they were tapped and extended, provided the source and the foundation of IB as we know it today. With this path came a set of elements that were commonly considered and embraced as "belonging" to the field. Imports, adapted as they were, included not only theories and methodologies but also legacies and implicit assumptions concerning the very nature of the field, including, for instance, the audiences we were addressing and the topics and lenses deemed "legitimate." While not deliberate, the process resulted in the formation of a "canon," to the exclusion of others, that we label "neglected" elements. The current state of the field is amenable to asking the next "big question(s)" because while it rests on stronger theoretical foundations, it simultaneously needs an open and eclectic approach that will help circumvent the "mix and match" issues of the early period (Buckley \& Lessard, 2005: 596) and allow us to focus on a new core set of issues. Hence, looking back will permit us to re-integrate and resurrect the neglected elements to help propel the field forward.

Some might criticize the endeavor as "kicking at open doors" while others may pinpoint publications that "prove that few others published" in the neglected areas. Our point is not to praise or to criticize, but to draw attention to what more needs to be done. For instance, do we adequately explain the impact of China's Belt and Road Initiative or merely refer to it as yet another governmentsponsored foreign direct investment (FDI)? Were we able to predict the recent rise of nationalism and populist ideology across the world as an alternative to globalization? Do we view it as a temporary aberration? Can we explain global income and wealth inequality as both a trigger and a product of cross-border trade and FDI? Do we have a theoretical platform from which to explain which companies should not internationalize, whereas our past efforts were directed at why they do? Do we have a theoretically anchored and methodologically rigorous way with which to look at cultural differences, or are we doomed to continue using convenient formulas even when proven misplaced? Do we understand the impact of political, economic, or social crises on firms, managers, and employees? In this paper, we focus on IB's disciplinary roots to show how such questions can be raised and eventually answered.

We discuss neglected elements in the following five clusters: audience and actors, locations, environmental layers, history, and interactions, which loosely correspond to the main building blocks of social action systems (Merton, 1996) and are consistent with the underpinnings of IB's interdisciplinary foundations (Dunning, 1989). Together, these groupings form the complex world of IB; covers its basic signposts; and guides its reach, scope, focus, and direction. This framework constitutes a "film negative" or mirror image; that is, it consists of elements that are not currently used to their full potential, including: (1) AUDIENCE, the audience for which we write and the groups and firms (actors) who are the "market makers"; (2) LOCATIONS, the geographies that constitute markets (broadly defined) of interest; (3) ENVIRONMENTS, the macro layers in which markets are embedded; (4) HISTORY, the prior path deemed relevant; and (5) INTERACTIONS, the bilateral/multilateral relationships among the players at the national and geopolitical level, as well as the interrelationships among the elements of the framework.

\section{NEGLECTED AUDIENCES AND ACTORS}

We start with a question with a seemingly obvious answer: for whom do we write? Who is our audience? The "usual suspects" include, first and foremost, multinational enterprise (MNE) executives, nongovernmental organization (NGO) leaders, and policy-makers. The broad literature, however, tells us that this question is important but is not as obvious it may look (e.g., Tenopir, Dalton, Fish, Christian, Jones \& Smith, 2016). The fields we build on, such as anthropology, sociology, economics, and political science, have a relatively clear view of the constituents with which their research converses as well as the presumed listeners, be they scholars, practitioners, policy-makers, opinion leaders, and the like. In IB, we implicitly address a subset, that is, Western MNE executives. Policy-makers now have their own dedicated IB journal, a recognition of their position as a relevant audience at the same time that it is an acknowledgement of their seemingly distinct interests. Overall, attention is primarily paid to how MNE executives develop international know-how through investing time and effort in activities, communications, and discussions aimed at improving understanding of the global marketplace (Bouquet, Morrison, \& Birkinshaw, 2009).

There are numerous studies on how MNE executives prioritize their attention to certain regions, 
global trends, ideas, and technology (Birkinshaw, Bouquet, \& Ambos, 2007; Dunning, 1996; Rugman $\&$ Verbeke, 2001). Most of those executives hail from developed nations, primarily the United States, and only a few take the local firms' perspective, even where highly relevant, as in the case of a cross-border joint venture where a comprehensive picture requires, by definition, incorporating the developing parent's perspective. As our field expands and develops, so should our audiences. Executives of non-U.S. MNEs, founder-managers, small- and medium-sized enterprise (SME) leaders, craftsmen, migrants, and other neglected groups need to be addressed, not only so we can tend to their needs but also to enhance our understanding of what may or may not be unique about our current main MNE audience. Not less importantly, by studying whether those neglected audiences follow similar patterns on such key issues as knowledge transfer, we can develop universal theories and/or identify contingency factors that we could not ascertain otherwise. In turn, this will widen the net and introduce new areas for research (e.g., Autio, 2005; Boddewyn \& Iyer, 1999) while leveraging broader scholarly talent (Cantwell, Piepenbrink, \& Shukla, 2014).

Similarly, while we conveniently add a concluding paragraph on implications for practitioners, do we really write for both authors and practitioners? Is it at all possible to address both of those audiences in the same breadth (Cuervo-Cazurra, Caligiuri, Andersson, \& Brannen, 2013)? Do we also target consultants? Within the scholarly community, is our audience confined to our IB colleagues, or does it extend to those in other business fields, social science faculty, and/or humanity scholars in area studies? If yes, does that mean that we should better leverage their respective theoretical frameworks and methodologies (e.g., Cuervo-Cazurra, Andersson, Brannen, Nielsen, Reuber, 2016)? Should we "translate" our findings to their often distinct scholarly language?

Furthermore, when the IB field was in its infancy stages, borrowing from foundational disciplines was needed (Dunning, 1989), but just what are our foundational disciplines? For instance, while Dunning (1989) called for closer connection to such disciplines as geography and political science, Shenkar (2004) questioned the very notion that IB was rooted in economics in general and in Hymer in particular, arguing that sociology and anthropology as well as integrative fields such as modernization and comparative studies were at least as important. And whereas there is consensus on the need to build on IB's interdisciplinary strength (e.g., Cantwell \& Brannen, 2011), there is often little by way of specification, particularly about how it can contribute to other fields rather than merely borrow from them. For instance, research on cross-border strategic alliances can make a viable contribution to international relations and political science disciplines (Shenkar \& Arikan, 2009: 3). Political scientists point out that states often behave like business firms (Keohane, 1984) whereas nation-states behave like nation-states (Krasner, 1978), but firms may be drivers of national strategies as much as their outcomes.

\section{Neglected Groups}

To a point, the audiences we speak to determine the actors we consider. A byproduct of the aforementioned implicit identification of MNE executives as our target audience has been the widespread exclusion of other groups, empirical (e.g., Huy, 2011; Neelankavil, Mathur, \& Zhang, 2000; TsuiAuch \& Möllering, 2010) and theoretical (e.g., Meyer \& Peng, 2016), exceptions notwithstanding. We typically focus on senior-level managers, assuming that concentrating on the Top Management Team (TMT) provides a sufficient link between the macro and the micro (e.g., Sambharya, 1996). Precisely because it is not, we tend to confound individual and team decision-making with the actual decision process and underestimate the role of other viable players in decision-making, strategizing, and implementation. These "others" are entry, mid-level, and rank-and-file employees, resulting in underappreciating and underutilizing the dynamics of underrepresented people (Vardi \& Hammer, 1977) and a neglect of their particular operational styles as well as group and individual interests. An extensive amount of economic activity and decision-making takes place among midand entry-level managers; in participative organizations, even line workers are involved in decisionmaking (a national variation in its own right, as in the representation of unions on German boards). Mid-level managers occupy a unique position: they are representatives of national culture and society, have specialized knowledge, and have direct authority over a larger number of workers than their senior superiors (Neelankavil et al., 2000; Peschanski, 1985).

Founder-managers are an important subset of decision-makers (Kahnweiler \& Thompson, 2000). We implicitly assume that entrepreneurs hold the 
same cultural values as the executives from whom the original data was collected, but entrepreneurs, almost by definition, break the mold (Lawler, Chen, $\mathrm{Wu}$, Bae, \& Bai, 2011). In addition, immigrants, substantially represented in the entrepreneurial community, are typically labeled under blanket terminology (e.g., McMullen \& Shepherd, 2006; Sarasvathy, 2001; Shane, 2000), their ethnic origin and immigration history often neglected. The same is true for career path. For instance, many Chinese MNEs and startups have CEOs with humble beginnings, starting as factory workers (Hout \& Michael, 2014) who may strive to distance their firms from state and collectivist management styles.

Oettl and Agrawal (2008) study labor mobility and externalities that accrue to knowledge flows among inventors by looking at how knowledge moves with workers from Siemens in Germany to IBM in Canada. A great deal of economic activity, knowledge transfer, and creative capability crosses borders through immigration. In addition to mobility of white-collar workers and codified knowledge transferred across borders via patents, blue-collar workers and tradesmen as well as craftsmen immigrate and carry tacit knowledge with them. Furthermore, while some mobility might be voluntary, in other cases it may be forced; either way, the knowledge embedded in an individual will transfer without intellectual property protection.

According to the United Nations (UN) Population Division and the Migration Policy Institute, the number of immigrants stands around 258 million annually (roughly $3.4 \%$ of the global population). While the number fluctuates year to year, the 1960 to 2018 period shows an annual increase from 77 million to 258 million, a significant number. When a historical perspective (to be separately discussed later) is applied to immigrant mobility, the boundaries of IB research can be extended and put to good use. A German craftsman emigrated to the U.S. in 1853 and launched Steinway \& Sons, transforming the piano industry. However, in the traditional and current selection model, this type of data would have been omitted. A way to remedy this is by taking a sociological perspective on markets and on social, political, and economic institutions (Levy, 2008). In turn, research may redefine our audience to include, for instance, politicians and policy-makers and, on the scholarly side, political scientists. For instance, when Chinese textile and apparel workers arriving in great numbers in the Italian town of Prato to take advantage of the coveted "made in Tuscany" label, the Chinese firms did more than just shift production, but had a direct role in shifting Prato's far-left political views to far-right and extremist views and had an impact on various other businesses and institutions in the region (Goodman \& Bubola, 2019).

Although much IB research shows how locationspecific advantages entice and attract MNEs, there is a bigger contribution in incorporating the neglected people and groups to study in this exchange. Nearly all Chinese in Prato come from Wenzhou, a town near Shanghai (Max, 2018); of the 50,000 Chinese workers in Prato, during the Covid-19 pandemic “there wasn't even one case of COVID contagion" because the workers went into voluntary lockdown 3 weeks before the first confirmed case in Italy (Ognibene, 2020). After returning from the Chinese New Year holidays, the workers in Prato (and their families) self-quarantined. While culture-based explanations have implications for flexibility, adaptability, and conformity, some cultural artifacts can lead to superior outcomes for coordination under turbulent times and uncertainty (Shenkar, Luo, \& Yeheskel, 2008). Thus, rather than looking at the main effects of cultural dimensions, one alternative approach could be to focus on the interplay between how cultural artifacts influence the handling of unexpected situations and business issues (Shenkar, 2001, 2012). In this example, the interaction between people, groups, context, and host society sets the stage for a unique natural experiment. Hence, one could argue that the cultural make-up of MNEs may represent endogenous sources of action and reactions. A likely prediction for Prato's Chinese workers after the pandemic will be based on how the local authorities benefited from the subgroup behavior in this micro-region in a subnational context.

\section{Neglected Firms}

We study mostly large MNEs and, much more rarely, the SMEs that play a vital role in trade and, admittedly less so, in FDI. According to the U.S. Small Business Administration (SBA) Office of Advocacy (advocacy.sba.gov), small businesses accounted for $44 \%$ of the U.S. economy ( $\$ 5.9$ trillion) in 2019. Globally, SMEs represent 95\% of firms and $60-70 \%$ of employment and new job creation in Organization for Economic Cooperation and Development (OECD) economies (OECD, 2019). 
To define SMEs, we use convenient but arbitrary cutoffs, e.g., up to 250 employees in Europe, 200 in the OECD, and 500 in the U.S. The SME category is rather broad, ranging from "micro" firms with less than \$1 million in revenue to "middle market" firms defined as having up to $\$ 1$ billion in annual revenue, according to the National Center for the Middle Market (Farren \& Makhija, 2021). Employment numbers can vary even within the same country. For example, while the SBA estimates that $60 \%$ of all new jobs are in SMEs, others find that small firms hardly contribute to job formation (Dunne, Roberts, \& Samuelson, 1989); and overall empirical evidence suggests that firm size is not a good predictor for labor intensity, job creation prospects, and growth, among other impacts (Beck, Demirguc-Kunt, \& Levine, 2005). SMEs are not necessarily suitable for comparison of developing and underdeveloped countries (Brown, Medoff, \& Hamilton, 1990), especially when taken out of context. For instance, the finding that in SubSaharan Africa large firms are the dominant source of job creation in the manufacturing sector (Biggs, Vijaya, \& Shah, 1998) must be qualified, first, that these firms are foreign MNEs, and second, that the industries in which they operate require heavy capital investment.

While the MNE is germane to IB research and has been at the center of the presumably foundational work in the field, limiting research to this group distorts and distracts from the IB mission (Shenkar, 2004). To obtain a comprehensive and representative picture, small firms, entrepreneurial firms, and long-standing "mom and pop" stores that make up the socioeconomic fabric in many countries should be included. Neighborhood bakeries, pharmacies, and hardware stores among others that are owned and operated by the founder or inherited from forefathers do not fit the conventional representation of entrepreneurial firms that have become a focus of interest. Surprisingly, with the exception of a few recent studies (e.g., Banalieva \& Eddleston, 2011), internationalization of family businesses is one of the least-examined IB topics; when at all studied, they are treated as a subset of SMEs, lumped together as "small and family-owned businesses" (e.g., the U.S.: 80\%, Kirchhoff \& Kirchhoff, 1987; Asia: 38\%; Europe: 43\%, Faccio et al., 2001). Family firms have unique approaches to dealing with governments, political parties, and institutions; they also have special features with respect to national origin, culture, ideology, and national history. For instance, Boellis, Mariotti, Minichilli, and Piscitello (2016) find strong evidence that during internationalization, Italian family firms prefer greenfield investments versus acquisitions due to risk-aversion. Entry-mode choices are subject to access to capital, experience, expertise, and home-host country dynamics; and entry into certain countries is only permitted via international joint ventures (IJVs). One would expect family firms to enter new markets through trading partners with whom they have arms-length contracting. For instance, family-owned Italian fashion houses (e.g., Fabiana Filippi, Georgio Armani) pursue different entry modes than family-owned Italian pharmaceutical firms (e.g., Angelini, Flamma). Furthermore, the information age gave birth to new firms that are "pure Internet firms" (Brouthers, Geisser, \& Rothlauf, 2016a, 2016b) who locally source resources and capabilities (as in talent) but operate in complex clusters, networks, and value chains across the globe (Alcácer, Cantwell, \& Piscitello, 2016).

Recalling neglected firms will enable IB research to (1) account for how firms respond to changes in their environments, and (2) allow us to explain things at the individual level, consistent with Cyert and March's (1963) classical admonition that people, not firms, are the ones that make decisions. For instance, how do firms react to repeated economic and social shocks in their countries? Some scholars focus on MNE reactions through subsidiary location choices and reconfiguration of geographic domains for firms' survival (e.g., Dai, Eden, \& Beamish, 2013); others extended the notion of flexibility and organizational fit to the conditions, environments, and capabilities to rearrange organizational boundaries (e.g., Buckley \& Casson, 1998; Caves, 1998). Though the emphasis on flexibility is center-stage for MNEs, for small firms that are owned and operated by one or few people, the oft-touted SME advantage of flexibility is actually limited. SMEs survive by balancing path dependency with internal control (Lubinski, 2011). In comparison to large MNEs or international new ventures (Mudambi \& Zahra, 2007), small sole-proprietor firms lack slack to rearrange or to reorganize their activities. When a pandemic such as Covid-19 triggers a shutdown, MNEs might shift production to other geographies, but soleproprietor companies must shut down and survive via consumption smoothing (Collier \& Goderis, 2009; Di Martino \& Vasta, 2010). Faced with unexpected natural disasters, SMEs have been proved better than governments at smoothing 
consumption and do not rely on the structural adjustment that formal institutions and large firms require (Collier \& Goderis, 2009).

Finally, the argument that SMEs are of lesser interest since much global trade consists of internal transfer among MNE affiliates misses the point. A National Center for the Middle Market study for the Metropolitan Policy Program at Brookings surveyed not only firms that internationalized but also those that did not (a strategy that may well be extended to IB research as a whole) (Gootman, Sio, Shenkar, \& Stewart, 2016). The main obstacle for the latter seems to be lack of knowledge, a finding that is not only interesting in its own right but also one that suggests a potential policy role for IB - to augment the global knowledge of SME owners and executives - thus contributing to their global engagement, in turn making them even more viable research targets.

\section{Neglected Locations}

The foundational disciplines of IB have a clear understanding of geography. These disciplines are blind to the identity of locations as they focus on various phenomena and track events across the globe. For instance, with respect to traditional economic analysis of costs, the logic is straightforward: the world is flat and the input-output tables report standardized intermediate good prices, costs, and volume (Cantwell, 2009; Dunning, 2009). However, in IB, firm activities by definition are geographically dispersed across multiple nodes and business lines. In the case of MNEs, the activities constitute a network with a clear epicenter (Cantwell, 1995), and the activities in the nodes are considered and compared with respect to those in the center (Rugman \& Verbeke, 2008). As the IB trajectory diverged from its foundational disciplines, a number of countries gained special attention. So, while the choice of certain locations for given topics using a particular theoretical lens introduces a bias in all fields, these common combinations have a greater probability of disruption in IB because the international variation itself is the focus.

In this paper, we draw attention to the benefits of reintegrating the under-emphasized, -estimated, or -utilized research locations to explain why researchers would want to include a particular country (or countries) over others. There are reasons why an attention bias of IB scholars, analogous to the behavioral explanations of international attention spans of MNEs (Bouquet et al., 2009), is influencing location selection. First, it makes practical sense to focus on a region if it is a major economy. However, at the same time, small countries or economies may be of interest on theoretical and or methodological grounds. Research that uses an underrepresented region for its own sake makes little sense unless there is a theoretical justification for doing so. For instance, in Meyer, Li, and Schotter (2020: 544, Table 3), the majority of home and host locations are "the usual suspects," i.e., the U.S., the UK, Australia, Ireland, Japan, Spain, Canada, Sweden, Italy, Germany, China, India, Korea, and Taiwan. The rest of the countries are grouped under broad categories such as emerging economies, advanced economies, advanced and emerging economies, as well as "other" economies.

As of 2020, the UN recognizes 195 countries and two observer states. The International Monetary Fund (IMF) classifies 23 of those as emerging markets; while the World Bank identifies 19 countries in the Middle East and North Africa region; and the UN lists 48 countries, six non-UN states, and six dependents (areas of special sovereignty) in Asia. Despite this wealth of different countries, regions, and geographies, the IB research context is limited to a few countries and or groupings that are sometimes hastily put together, such as "BRIC" (Brazil, Russia, India, China), a Goldman Sachs moniker that lumps together nations with more differences than commonalities. A separate question of interest is whether such groupings have an impact on firms' location choices (e.g., identifying the BRIC as FDI priority) or its structure (e.g., having a BRIC division), of which there is anecdotal evidence.

The IB field's flagship journal, the Journal of International Business Studies (JIBS), has been careful and exemplary in encouraging geographical inclusivity. There was concerted effort as early as the 1990s to encourage broader national representation in IB research (e.g., Thomas, Shenkar, \& Clarke, 1994). Tellingly, in a precursor to Meyer et al. (2020), the probability of a country ranking higher on the list was explained by the focal country's trade relationship with the U.S. This dominant anchor against which other countries have been predominantly compared supports the attentionbias explanations. On a related topic, JIBS authors' geographic diversity between 1972 and 2014 shows a positive trend of geographic expansion, but still leaves large swaths of uncovered territories (Cantwell, Piepenbrink, Shukla, \& Vo, 2016). 
While a quantitative review of geographic location and authorship diversity is beyond the scope of this paper, we focus on the potential gains from higher inclusivity and the drawbacks of omission. We argue that neglecting a large number of countries results in a loss of valuable knowledge, not only in terms of economic and geopolitical importance but also in terms of theory development and testing opportunities. There are several exceptions for research in the difficult-to-collect data locations: for instance, Bangladesh (Branzei \& Abdelnour, 2010), Iraq (Jeong \& Weiner, 2012), and Libya (Darendeli \& Hill, 2016). Also, several papers encompass a wider net to account for multilevel phenomena, spaces, processes, and methodologies (e.g., Deng, Delios, \& Peng, 2020; Meyer et al., 2020; and Nielsen et al., 2020).

There are at least three types of omission: (1) inconvenient and inaccessible data such that the target nation might not be available or suitable for study at the time (e.g., North Korea, Iran, Afghanistan); (2) scale, that is, a country that seems too small to matter, e.g., Samoa, although in looking at American Samoa (a U.S. Territory) versus independent Western Samoa, one could compare the impact of institutions while holding the culture constant; and (3) locations omitted despite their economic importance, e.g., Indonesia, Egypt, Ireland, Turkey, and Oceania (Punnett \& Shenkar, 1994; Shenkar, 2001, 2012; Shenkar et al., 2008), possibly because of a paucity of researchers in the field. While the first and third groups seem selfexplanatory, we should add a word about the second.

In the early 1960s/1970s, location was incorporated into the product cycle theory of trade and FDI (Vernon, 1966) and Dunning's (1970) eclectic theory of FDI. In latter years, however, the focus shifted from country-level to firm-level analysis (Cantwell, 2009). Cantwell (2009) drew attention to the complex nature of ownership and location advantages of the "modern" MNE and argued that past MNEs faced simpler patterns through product cycles or the internationalization process models (i.e., Johanson \& Vahlne, 1977). Therefore, motives for seeking assets in specific locations shifted to asset recombination and competence creation when networked MNEs seamlessly used multiple locations (Cantwell \& Mudambi, 2005; Nohria \& Ghoshal, 1997). Networked subsidiaries in an interconnected MNE system (Cantwell, 2009) place emphasis on firm-specific integration and transfer capabilities rather than immobile location-specific advantages. Therefore, we have seen several cycles where geography and location were salient but not so fashionable, starting in the 16th century with the rise of imperialism, colonization, and economic development (Gartzke \& Rohner, 2011).

In the meantime, the countries that were repeatedly studied are etched into our mental map (Shenkar, 1994; Thomas et al., 1994), forming cognitive orientations (Kaplan, 1973) of a U.S.centric scientific community (Boyacigiller \& Adler, 1991). The problem of omitting countries or regions is not just a matter of focusing on images and impressions that we are preconditioned to receive via cognitive filters. Selectively focusing on what is readily available results in what geographers call "cultural decay." The composition and structure of cultural, political, economic, and sociological systems is conceived in a network of relationships. Research centered on network construction and the use of network methodology factors in constituents' individual and collective attributes (Bourdieu, 1984; DiMaggio, 1987). Cultural decay is an outcome of dispositions since attention is on what is popular and highbrow (Lizardo, 2006).

The "perpetuating cycle of parochialism" can be overcome by shifting the focus from convenient datasets and popular countries to include lessvisited geographies and overlooked locations (Thomas et al., 1994: 685). For instance, Rugman and Verbeke (2004) pinpoint the problems associated with the limited scope of using one or two geographic clusters, while Ronen and Shenkar (2017) illustrate the impact of using a limited number of cultural clusters for the overall clustering map obtained. Ghoshal (1987) and Yip (1992) explain how MNEs see national barriers as eroding, whereas others view firms following a semiglobalizing, regionalist perspective (Ghemawat, 2003; Rugman \& Verbeke, 2004). As an example, if research follows the same patterns and focuses on the economic activities of U.S., European, and Chinese firms in their domestic markets (to and from), the new reality of Chinese and Indian firms investing heavily in Africa will be overlooked. Such an omission is critically detrimental to the field. Entry into and activity in understudied regions and markets present opportunities for new and valuable insights for IB. Gravity models of geography research, legal and structural changes in new target locations, post-colonial growth in formerly colonized regions, corruption, regional competitors, and small and local firms' defenses against entry 
are among the new directions we should consider for ensuring the durability and relevance of our theories.

Finally, political geography is the spatial analysis of resources separate from national interests, and geopolitics is the analysis of causality between how the geography of a nation triggers political events. Starting with David Ricardo (1817), we incorporated a great deal of knowledge from how factors of production move across countries and regions. We have, however, neglected the salient implications of geography on firms, institutions, and nations. While we did not realize the need to convert geopolitical knowledge into geoeconomic implications, this was mostly because the better part of the 20th century was built on the premise of globalization and the end of the nation-state. Empirically, we observed all-powerful MNEs and soon-to-be giant "born global" firms, and our treatments rightfully followed the Ricardian doctrine. Especially when the world moved into a more "integrated economic, cultural, and economic reality," geopolitics took a backseat to geoeconomics and geogovernance of firms (Tuathail, 1997: 37).

Next, we illustrate how IB research can expand the construct of geographic locations instead of treating it as one of the control variables. For instance, why should one care about a very small country like Samoa? As noted, the existence of an independent nation, Western Samoa, side-by-side the U.S. Territory of American Samoa provides an opportunity to compare institutional impact while holding culture constant. In the natural experiment setting of Western Samoa versus American Samoa, the unique setting presents an invaluable context where one can control for anthropological foundations of a culture that is split into two countries but has developed different institutions, subcultures, and economic and organizational systems. Since Western Samoa is an independent nation and Eastern Samoa is a U.S. territory, the context presents IB scholars a controlled environment to test several IB dilemmas and theories.

Interestingly, seldom-visited countries and nation dyads in IB (e.g., Greece-Turkey, EgyptSaudi Arabia, Kuwait-Iraq) are often the focal point in foundational disciplines such as political science, international relations, anthropology, sociology, and economics. For example, these locations present opportunities to test cultural- and institutional-distance arguments developed in Shenkar (2012), Zaheer, Schomaker, and Nachum (2012), and Luiz (2015) where the complexity in cultural interface and identity formation in different countries can explain variance in cultural schisms, ethnicity, religion, and the like. Similarly, using less-often-used focal regions in replicating studies such as Joshi and Lahiri (2015), Brouthers, Marshall, and Keig (2016a, 2016b); and Harzing and Pudelko (2016) may provide contributions to the IB knowledge and further enrich the field.

\section{Neglected Environmental Layers}

Economic, social, political, and cultural environments dynamically evolve together with a nation's institutions. The resource endowments, technology, and social conditions along with the dynamics that are both within and around a nation constitute a "fit." Veblen (1898) argues that each nation has different ideologies and economic systems that evolve to the Malthusian "survival of the fittest" element in their global economic affairs. He explains that U.S. economic institutions are selected out because of market competition and cannot be replicated elsewhere. Chandler (1977) builds on this premise and argues that the fit between corporate structure and evolving environments determines survival. For instance, the role of the state in the economy and varying degrees of laissez-faire explain the management style in China, Japan, and the U.S.; but state involvement is evolving with respect to national culture as well as political and social pressures. Noninterventionist U.S. policy has been interrupted several times. In 1945, through the World War II Employment Act and during the Kennedy administration, Keynesian measures for maintaining full employment are examples that fit is an outcome of continuous alignment between ideologies and economic systems.

\section{Neglected Ideologies}

Philosophy historians call the early 19th century the age of ideology because nearly all the "-isms" were devised by secular beliefs that replaced traditional religious and faith-based concepts. There are many and often incompatible political ideologies with competing ideals, principles, doctrines, myths, and symbols (Freeden, 2001). There are three non-Marxist approaches to classifying ideologies. The first sees ideologies as closed and doctrinaire, impervious to empirical evidence; the second as empirically ascertainable attitudes that can be explored by behavioral methods; and the third as indispensable mapping devises of cultural symbols that shape sociopolitical life (Freeden, 2001: 7174). 
Each ideology has a different set of "correct and legitimate meanings" of political ideas and means of control. In IB research, we have chosen to focus on a limited subset of these ideologies. With the exception of a few studies (e.g., Mariotti \& Marzano, 2019; Morck \& Yeung, 2007; Witt \& Jackson, 2016), we hardly study how ideologies impact national or organizational cultures, trade, and economic activities and how firms are organized around the world with respect to differences in and shifts across ideologies.

Starting with the post-colonial period of the 1800s, ideologies emphasized ethnicity and identities under social constructs as nations gained momentum (Sibley \& Osborne, 2016). Ideology was formed by the political elite and disseminated to the masses by institutions and educational systems (Ansell \& Lindvall, 2013). This is not to say that ideologies, often embedded in religions and or philosophies, did not play such a role before. (For instance, the Confucian analects were read to rural dwellers many centuries earlier.) But in modern times, their form and momentum has taken on an independent life with historical patterns and paradigm shifts following diffusion trends with time gaps in between.

IB research caught up with the trends only later and rarely considered the ideologies that drove the transition from empires, kingdoms, and city- to nation-states. Decolonization in political science and nation building in international relations independently developed in two distinct research streams (Wimmer \& Feinstein, 2010). Since modern IB research witnessed first-hand the globalization and internationalism ideologies and did not keep track of the prior movements for which historical sociologists would account, this research underutilized recurring ideologies and their impact. For instance, the current thrust in nationalism was a social driver in the early 1800s, 1860s, 1910s, 1930s, and 1960s. However, we do not systematically address societal differences and commonalities with respect to underlying ideology, nor do we examine how the society and its institutions evolve, with a few notable exceptions (Alvarez \& Rangan, 2019; Cantwell, Dunning, \& Lundan, 2010). We tuned out of this evolution, or rather ignored the oscillation away from globalization, liberalism, internationalism, and multilateralism. Instead, our research engine is "still full steam ahead" on the notions of global economic interconnectedness and efficiency seeking.
Increased sentiments in a country that favors isolationism and protectionism results in increased patriotism or love of country (Sullivan, Fried, \& Dietz, 1992). Patriotism incorporates socialization processes that build on cooperative approaches to develop and nurture a sense of belonging (Karasawa, 2002) and persistent self-sacrificing personal interest in favor of national interests (Druckman, 1994). Patriotic socialization and attachment to ingroup identities nurture ethnocentrism, which is conformity to prevailing national values and rejection of other nations as out-groups (Doob, 1964). When healthy patriotism escalates into feelings of superiority and dominance, nationalistic feelings take over and build negative attributes such as animosity and hostilities (Balabanis, Diamantopoulos, Mueller, \& Melewar, 2001). The escalation from patriotism to nationalism requires a set of nation-oriented beliefs and political-elite driven ideology, as well as perceptions of superiority at various societal levels. A nation's memory makes it possible to escalate positive sentiments around patriotism into an endemic and emphasizes the negative aspects of pride and hubris resulting in nationalism (Brubaker, 1996, 2004).

It is helpful to visualize ideology as a layer laid over culture, and the two can reinforce or conflict. For instance, Kenya, a pluralist society under colonialism, experienced rapid change after independence in 1963. However, the pace at which colonial institutions went through transformation into independent-state institutions was asynchronous. The society fell into dispute in behavior and activities due to misalignment in structures (Abel, 1974) and culture (Ndegwa, 1997). Also, in the 1970s, post-colonial Kenya went through a Marxist discourse and then in the 1980s a capitalist structural discourse, which by definition is a natural conflict (Hetherington, 1993).

During the transition from post-colonial to precapitalist society, pluralist and multiethnic Kenyan democracy strongly conflicted with the national culture (Ndegwa, 1997). In contrast, research on several Latin American countries provides accounts of ideology and culture reinforcing each other during different periods. For instance, Bolivia, Mexico, and Venezuela experienced congruence, consistency, and continued socialization during agrarian (land) reforms (Levine, 1974). Industrialization in Guatemala is tied to the impact of the Spanish conquest and the colonial experience on national cultures in different countries in the region (Foster, 1960). The culture-ideology overlap 
is not a unique condition for countries with colonial experiences. For instance, although the Chinese culture is very hierarchical (Ronen \& Shenkar, 2013), Maoist ideology emphasized egalitarianism (Harding, 1982). Mao's “Twenty Manifestations of Bureaucracy" (1967), the Great Leap Forward (1958-1961), and the Cultural Revolution (1966-1976) are Maoist alternatives to rational bureaucracy (Whyte, 1973). Such conflicts between culture and ideology present an opportunity to dig much deeper into the impacts of both.

Integrating the neglected ideologies in IB research will enrich the explanations around causal mechanisms. At the individual, firm, institution, and nation levels, incorporating shifts across the social fabric will help the directionality of many arguments. For instance, although national and corporate cultures are strongly impacted by ideology, research seems to ignore shifts in ideology across decades (Jones \& Khanna, 2006). Furthermore, at the firm level, the choice of organizational governance mechanisms such as acquisitions will reflect the general trends and sentiments of the home and host countries, enabling some while impeding others (Buckley, Doh, \& Benischke, 2017). Another example connecting neglected ideologies and IB is via integration of international relations theories (e.g., realism, constructivism, liberalism) with firms' behavior in international markets. For instance, realism theory focuses on conditions when a nation lets go of the higher moral ground and uses practical actions to maneuver in international exchanges for the benefit of gaining advantages, power, wealth, and status (Gowa, 1994; Gowa \& Mansfield, 1993). For IB research, how an MNE conducts business and how these actions are interpreted by hosts is critical. Mining companies, for example, are often criticized for placing profits ahead of environmental damage. However, the asymmetry between home- and hostcountry constituents in regard to these mining companies can be explained through the lens of ideologies (Geary \& Aguzzoli, 2016). This perspective recognizes the permeability between the concepts of international relations and may augment the topics studied in IB research.

\section{Neglected Economic Systems}

As new organizational forms appear and the old forms vanish, those who choose the new forms gain legitimacy and face increased chances of survival (Hannan \& Freeman, 1986, 1989). The ecological process and selection mechanisms favor the new forms since the new replaces the old by addressing the shortcomings of the existing systems (Ruef, 2000). This dynamic choice model and underlying mechanisms help explain the shifts between capitalism and socialism (Judge, Fainschmidt, \& Brown, 2014; Redding, 2005). As economic systems, neither exists in its pure form and the most extreme cases do not exist at all (Schumpeter, 1950), a position quite like that of Max Weber's ideal type (whose real-life mode varies by ideology and regime).

Socialism has undergone several evolutions, ranging from central planning to communism and degrees of command economies (Stalinist, Marxist, etc.) For instance, Marxian social organization (Gesellschaftsform) uses value and price systems in a comparative manner to critique the inefficiencies of the capitalist system that operates in a world of "commodities." Similar to the explanations by Polanyi (2001), the economic system and social rationalization focus on the maximization problem (Weber, 1961). Capitalism similarly went through several evolutions (Polanyi, 2001), depending on where and when it was instituted, ranging from Guild Socialism in England (Weber, 1961), to liberalism in the U.S., the federal market economy in India, and nonliberal corporative forms elsewhere. These evolutions reflect the positivist, relativist, and political approaches of their time. For instance, the liberalism and economic efficiency focus of Adam Smith was replaced by principles of political economy in David Ricardo's (1817) treatments, then by general equilibrium theory, and by Schumpeter (1950).

The classical and neoclassical approaches in capitalism and socialist approaches in the postWorld War II world are now being challenged once more. Historically, evolution is triggered by crises. The control of coercive power is a competitive advantage of the state. Both political and economic institutions change during times of crises (North \& Weingast, 1989). In times of unrest, there is a constant reneging and complex rearrangement of institutions. As the monopolists of coercive power, states can use their fiscal and monetary powers to resolve economic disparities (North \& Weingast, 1989). For instance, the Ten-Year Crisis in England triggered monetary debates, the Grunderkrach Depression in Europe and North America (1873-1896) reinforced social policy before World War I, and the worldwide Great Depression (1929-1939) triggered the Keynesian welfare state and regulation. Effective and efficient markets 
require an economic system that is designed with an appropriately organized government, political and economic institutions, and a strong commitment from the state that honors the economic and political rights of its citizens (Weingast, 1995).

While capitalism and socialism are behind free market and socially planned economic systems (Witt \& Jackson, 2016), respectively, a neglected economic mechanism is market-preserving federalism. Many issues faced by today's developing nations were faced by developed nations in the past; hence, there might be opportunities to learn from the experiences of current leading nations. Yet direct replication is not possible, and today's circumstances do not fit verbatim. Nevertheless, of the last 300 years, the richest nations have had federal structures: The Netherlands in the 16th17 th centuries, England in the later 17th to 18th centuries, the U.S. in the late 19th to early 20th centuries, and modern China (Weingast, 1995). Federalism requires (1) a hierarchical political system in which there are two levels of government ruling the same land and people; (2) autonomy of each government that is institutionalized with selfenforcing restrictions (Riker, 1964); (3) subnational governments with primary responsibility over the economy; (4) lower governments that do not erect trade barriers and ensure common markets; and (5) lower governments that face hard budget constraints and cannot print money or access unlimited credit (McMinnon, 1997; Weingast, 1995).

There are slight differences between de jure federalism (e.g., Argentina, Brazil, and India) and market-preserving federalism (e.g., modern China). Unlike many suggest, it was not "coming out of communism" that led to the success of China over Russia since both came out of communism. Similarly, dissolved Iron Curtain countries were not able to capture China's momentum. Instead, many Eastern European countries were tied down in a long transitional period (Guriev \& Zhuravskaya, 2009). In contrast, China's relatively shorter experience with communism allowed its leaders to be more "pragmatic and less ideological (in the) pursuit of socialist economic principles, (with a) far less interdependent economy" (Weingast, 1995: 21). Chinese-style federalism preserves its vast market with a very close approximation to the aforementioned five principles. China's decentralized political institutions allowed local governments significant control over economic policy (Child \& Tse, 2001). In many parts of China, local governments enabled entrepreneurial startups and strengthened established firms that moved away from state ownership into state-controlled status (Walder, Isaacson, \& Lu, 2015). In many ways, England in the 18th century and modern China resemble each other. Both relied on prospering economic enterprises and expanding local resource bases, and the interests of local officials were closely aligned with local economic success. Furthermore, as evidenced in the China example, the durability of reforms (Witt, 2008) and shifts away from socialism to state-capitalism provides stark lessons to many established economies in Europe that pursue socialist and socially democratic economies (Li, Cui, \& Lu, 2014). While some have introduced Western biases and criticized the Chinese state capitalism model of market-preserving federalism as it gave rise to an uneven spread of economic reforms, these criticisms are probably premature (e.g., Jackson \& Deeg, 2008; Judge et al., 2014). In such a large country with many distinctive political, institutional, and cultural characteristics, the changes have taken a relatively short period of time (Biggart \& Hamilton, 1992).

Recollecting the fundamentals of economic systems will have at least two IB-relevant outcomes. First, revivalist systems such as market-preserving federalism will help explain how the new economic network is shaping up globally. The emergent forms support a different style of resource allocation in the new quasicapitalist systems (Boisot \& Child, 1996). Investment flows are assigned to areas that are most effective nationally, and the balance between state and local governments addresses the shortcomings of planning systems. It is likely that the overburdened industrial community and government officials in Europe and national capitalist firms and mostly centralized governments in financially weak South America will adopt their own paths based on the Chinese experience. Second, the field will benefit from addressing some misleading labels such as "transitional" or "emerging economies." Do transitional economies all share the same legacy or starting point? (They don't.) What are they transitioning into? (Recall the West's misplaced expectations of China turning into a free market democracy.) What is the threshold for an emerging economy to complete its emergence? (A similar question might address an entrepreneurial firm.) What do we call a country that has recently emerged? (Did Greece really cease to be an emerging economy when the EU made the call?) To offer visual cues of dichotomy for national growth might be convenient in categorization, but these simple 
distinctions are not suitable given the continuous nature of the variables. Hence, one can label someone's age as young, adolescent, or old, but much information is lost in categorization as a substitute for the actual number. IB research needs to acknowledge that countries do not have to transition into Western capitalism and that every nation is on a different evolutionary path and has a trajectory for growth (Arikan, Arikan, \& Shenkar, 2020). IB research is interested in bilateral and multilateral interactions between nations that are on different evolutionary paths and growth trajectories; we should not allow parsimony to exceed its usefulness threshold and become an obstacle to such observation and analysis.

\section{Neglected History}

Current IB research seems to implicitly assume that constituents are immune to sentiments between nations despite their histories. This assumption results in treating the political, social, and economic incentives and motivations between the parties in a misleading, homogeneous fashion (Arikan \& Shenkar, 2013). Such generalizations unnecessarily oversimplify complex systems with many variables across societies. In any society, multiple generations of individuals have been educated, conditioned, and socialized to conform to specific norms (Arikan et al., 2020). Societies have collective memories, but people's interpretations of historical events will vary across societies even though people share many aspects of the same culture. According to Zald (1996), all behavior is historical, and companies are not just instruments for creating products and profits; some activities are intended to show power and domination (Zald, 1993). For instance, some argue that Indian companies have increased the pace of acquisitions of British icons, the crown jewels of the UK, in a move to diversify their portfolios and seek underpriced assets. Another interpretation might be that India is engaged in reverse imperialism to show power. Tata Group acquired Tetley in 2000, Corus in 2007, Land Rover and Jaguar in 2008, and British Salt in 2010 and became the first company in the Fortune 500 rankings from a developing economy (Karnik \& Balachandran, 2016). In a variation on the product life-cycle model, Indian firms are relaunching defunct venerable British motorcycle brands such as BSA, which will be manufactured in India with some UK assembly and sold in the European and U.S. markets.
Until recently, IB research underemphasized the historical context and complex interfaces between national histories and how firms in those nations made strategic decisions (Jones \& Khanna, 2006). The lack of historical contextualization resulted in theoretical misrepresentation of causal relationships and empirically led to sample selection and endogeneity issues (Arikan \& Shenkar, 2013). With a few exceptions, the assumptions and contextualization were "immune" to a historical lens (Morck $\&$ Yeung, 2007). IB research needs to better integrate the causal relationships between historical markers and individuals, firms, institutions, and national memories. National identities reflect collective memories of dyadic conflicts between nations. The history between nations, especially those with a legacy of conflicts, triggers negative sentiments in both countries. If two countries have come out of a decade-long war with multiple casualties on both sides, sentiments on both flanks will be negative regardless of the reasons and who started the conflict. The feelings of antagonism may linger across generations in these countries for years to come (Arikan \& Shenkar, 2013). For IB research, both at the firm and the individual level, it is highly valuable to understand how animosity impacts the formation of firm alliances or mergers and acquisitions (M\&A) and deal consummation (Li, Arikan, Shenkar, \& Arikan, 2020), as well as consumer behavior (Harmeling et al., 2015).

The concepts of nation and country are used interchangeably. Instead of understanding the bilateral and multilateral linkages between nations' relational aspects in a network, most research compares countries one-by-one to the U.S., though the political, social, economic, and cultural variables do not resemble currency-pegging principles. Take animosity between nations as an example: (1) sentiments of antagonism between nations are asymmetrical; (2) within a nation, generations and cohorts within generations have different perspectives towards other nations; (3) managers in firms make decisions, but individually they are influenced by their identities - owner-managed firms will act differently from top-level executives at MNEs; (4) states use education as a propaganda tool and influence the way dyadic histories between nations are retained and remembered in their societies (Arikan et al., 2020). Scholars who only look at part of the puzzle and omit the rich nuances miss this context.

Nation-dyadic history is a key determinant of international activities because national and 
professional identities are strongly impacted by the past and reflect the collective memories of societies (Arikan \& Shenkar, 2013). Historical accounts are interpreted and relayed differently across generations. A generation that experiences a historical marker first-hand and another generation that hears or reads about the incidents by going through the education system have different reactions (Suzuki, 2013). Generational distance between the subgroups that are exposed to different education systems condition individuals differently (Berger \& Luckmann, 1967). Professional identities are also conditioned by education systems and are subject to historical socialization processes (Cohen-Scali, 2003).

Firms operate in societies and under the rules of nation-states. They need to adhere to fundamental political and social rules that establish norms in their societies (Arikan et al., 2020). Institutions set rules that regulate, monitor, and smooth out social interactions (North, 1990). In this macro equation, all variables are subject to change and "all behavior is historical" (Zald, 1996: 256). Social historical events are retained in the collective memories of societies (Zald, 1993), and negative sentiments are infused into social and collective memories (Halbwachs, 1950/1980) via socially constructed records and cultural artifacts such as books, museums, monuments, etc. For instance, the History Museum in Kaosiung, Taiwan, displays artifacts from the Japanese occupation of 1895-1945 and showcases Japanese institutions in a neutral to positive light. Attitudes toward Mainland China are somewhat ambivalent, with a prominent place given to "the $2 / 28$ incident" (the killing of demonstrators on February 28, 1949). The exhibit, which attempts to present both sides of the events, is considered by both sides to be offensive. This example demonstrates the complex nature and interactions of history with national identity and social memory. The national self (Taiwan) and the two primary countries (China and Japan) have an identity discourse. The discourse and conflicts are influenced by generations, and the discourse is the highest among current college students, roughly 70 years after the incident (He, 2014; Wang, 2017).

Remembering history will have at least two salient outcomes. First, it will influence many generations in a society. Through educational institutions, the influence will have direct and indirect effects through biases and stereotypes. National governments use educational institutions as propaganda tools and convey national agendas.
Such propaganda can take place at various age groups and education levels. For instance, the children's program "Sesame Street" was exported to Afghanistan in 2011 as "Sesame Garden" to "change lives in a war-torn" country (PBS, 2016). Two facets of history are critical: first, the sentiments between the nation-dyads need not be symmetrical; and second, generations across the society will have different interpretations. Therefore, the American sentiments against Afghans would be different from the Afghani sentiments against Americans; and a toddler in Afghanistan watching "Sesame Garden" would interpret these lessons differently from his or her counterparts elsewhere. A nation's history does not exist in isolation; countries should not be treated as isolated entities (Arikan et al., 2020). There is a strong relational aspect that ties countries together in a network of interrelated histories (Arikan \& Shenkar, 2013). For a long time, international relations scholars studied the networks of nations' international relations (Hafner-Burton, Kahler, \& Montgomery, 2009). The networks based on history at the national level impact firms by influencing countries' collective psychology, memory, retention, and experience (Arikan \& Shenkar, 2013) as well as at the intergovernmental and institutional levels (Ingram \& Torfason, 2010).

\section{Neglected Interactions}

IB is a rich and complex field, it is "free from any single core paradigm," and it does not pursue a single dominant research question (Doz, 2011: 582). The essence of being interdisciplinary, by its nature, requires the field to study interactions among theories, constructs, and fields. However, many critical interactions are omitted because the units of analyses do not match and the measurements are not conveniently converted to "acceptable empiricism" (Doz, 2011: 583). Instead, the field needs to acknowledge the complex interactions and institutionalize broader applications of theory and empirics. For instance, using microlevel lenses, if we study immigrant entrepreneurs' internationalization patterns, the question cannot be studied in isolation from the political and social interactions of the constituents. All this takes place at a particular time in history. Take the example of Chinese immigrant entrepreneurs in California during the Silicon Valley boom. Although Chinese entrepreneurial actions were undertaken in the late 1990 s boom period, Chinese emigration to the West Coast took place long before that in three 
distinct waves: the first wave was in the 1800 s for construction of the transcontinental railroad; the second wave was during World War II due to the military alliance (Magnuson Act); and the third wave was in 1965 (Immigration and Nationality Act of 1965). One would assume that the U.S. Congress mandates of 1882 (Chinese Exclusion Act) and prohibition laws in 1892 (Geary Act) seemingly would not have an impact on Chinese immigrants 100 years later in the 1990s. On the contrary, the 19 th-century laws were the only U.S. laws ever to prevent immigration and naturalization on the basis of race (clearly abolishing Chinese nationals). These immigration policies had economic and social implications a century later during the Silicon Valley boom in California (Triadafilopoulos, 2010). Hence, we emphasize several neglected interactions.

People and firms involved in the production of value and trading of commodities and institutions that are responsible for regulating or organizing economic activities are all part of a system that is best explained through economic anthropology. The system has a memory; the context is locationspecific; and it is comprised of several dynamics, including status, power, and community needs (Thompson, 1971). Firms make up the market side of exchanges based on scarcity, competition, and monetary mediation. States and institutions are in charge of status, power, and protection and make up nonmarket exchanges (Polanyi, 1944). Between the 16th and 18th centuries, powerful nation-states maximized benefits that accrued to the states through direct intervention and "distortions in institutions" using status and power, and these distortions linked the nonmarket to market exchanges (North, 1990). Hence, a history of the early trading companies occupies the intermediate space between capital holders and target locations. Nonmarket and market hybrid structures involve institutions that regulate mercantile activities, banking, finance, and commerce as well as transportation.

Between 1551 and 1874, there were several "India Trading Companies" that gained monopoly trading rights and mercantilist privileges on several key routes (e.g., British East, Dutch East, French East, Dutch West, Swedish East, Danish East, Royal African, and Muscovy Trading Company). For a long time, firms existed in nonmarket and market exchange systems side by side, and the hybrid existence was best represented by sustained economic structures across the different India Trading
Companies (Washbrook, 2010). Initially, the rights to property ownership and resource accumulation had distinct noneconomic criteria, as these belonged to sovereign kings. Starting with industrialization and liberal economic ideologies, a combination of family proprietorship and corporate identity enabled some of the trading houses use flexible strategies, access limited managerial resources, and "mitigate the transaction costs that remote management entailed" (Roy, 2014: 10). Regardless of the steady progression to capitalism that enabled private ownership and commerce, nation-states still governed and protected trade and were directly involved in it.

Giant trading companies that dominated economic life before the 20th century went through many structural changes, and many MNEs emerged. Companies like Japan's Sogo Shosha, Itochu, Mitsui, and Marubeni are examples of family-run conglomerates (i.e., zaibatsu ${ }^{1}$ ). U.S. traders like the United Fruit Company and Cargill, French traders like Cacao Barry and Louis Dreyfus, and UK traders like Swire, Glencore, and Dalgety are merchants that became MNEs (Jones, 2002; Clairmonte \& Cavanagh, 1988). In modern times, governments' intervention and states' involvement in trade closely resemble the 16th-century state operations, especially when there is an unexpected exogenous shock or calamity. For instance, in 1974, Czarnikow, a large British sugar-trading company, made two contracts with Rolimpex (Polish State trading company) to purchase Polish white crystal sugar. Due to bad weather, Rolimpex claimed force majeure and denied shipment. Czarnikow claimed inter alia since Rolimpex was an organ of the Polish State and could not ask to revoke the contracts (Lasok, 1981). In 2020, although there is no organic ownership stake in it, the U.S. government (1) asked Chevron, Halliburton, Schlumberger, Baker Hughes, and Weatherford International to halt production in Venezuela (Egan, 2020); and (2) related to the Covid-19 crises, asked $3 \mathrm{M}$ to stop selling masks overseas and sell them only domestically. President Trump accused 3M of "whining and acting like a sovereign nation," and told the firm to "get their act together" (Westwood \& Diamond, 2020). Government interventions are often expected but least desired unless the deals have the potential to threaten national security or to damage competition and markets, such as when a U.S. private equity firm wanted to acquire Cobham, an aerospace and defense group (Pfeifer \& Pickard, 2019). On the contrary, societies are more 
welcoming when crises seem to be massive and unexpected (Saez \& Zucman, 2020).

In contrast to 16 th-18th-century socioeconomics when nation-states pursued mercantilist policies to control trade and commodity prices, 18th-19thcentury state intervention focused on controlling trade, wages, production, and consumption (Hoover, 1942). State involvement in the modern period assumes the role of the developmental state instead of the interventionist state. This perspective was especially instrumental in Europe. Most European governments chose to modernize their national champions, and socialist governments protected vested interests at the expense of growth. For instance in France, President Mitterrand nationalized the banking system in 1981-1982. Also, circulation of elites (i.e., pantouflage) between large French firms (private sector) and civil servants (public sector) were exercised to communicate, coordinate, and consolidate information and activities (Ornston \& Vail, 2016).

The interaction between geopolitics, socioeconomics, and ideologies needs to be pondered because economic and societal organizations in both developed and developing countries move back and forth on a continuum between two extremes: liberalism and Marxism. Both extremes are utilitarian in nature. The parameters of the prevailing doctrines shift when unpredicted and unplanned phenomena happen or when ideology shifts occur (Schmiegelow \& Schmiegelow, 1975). The principle of mercantilism requires protectionism. For a nation to run a surplus and accumulate wealth, states must curb interest rates and incentivize and protect companies to industrialize. Germany adopted the "Germany First" model where Chancellor Merkel pursued persistent annual trade surpluses (e.g., $\$ 270$ billion in 2016, $\$ 300$ billion in 2017, $\$ 65.8$ billion in 2018, $\$ 15$ billion in 2019) (Kreijger, 2017; Deutsche Welle, 2020). As one would expect, consistent and persistent trade surpluses increase tensions between trading partners. Furthermore, rhetoric released during the surplus announcements frustrates political relations. (An example would be this announcement on Reuters: "the record surplus will continue to fuel the conflict with the U.S. and within the EU. European neighbors would benefit from stronger investment in Germany. Germany, however, would profit first and foremost" (Carrel, 2017)).

Another neglected interaction is the intersection of theory and country combinations. This interface is critical for the position of IB journals, led by JIBS, as not just theory-based but also theory generators, and is key to the aforementioned aspiration to reestablish its exports to other disciplines. As in the world of trade we cover, such exports depend on, among other things, developing IB's competitive advantage, which in turn depends on the ability to better connect between theory and the world it represents. A review of the literature will quickly reveal that some theory-context and theory-country combinations tend to be more common than others. Consequently, some markets, industries, locations, and types of firms tend to be "type-cast" as the appropriate research settings. For instance, transaction cost economics (TCE), likely the most popular theory in IB research, has individualism as a presumption (Brouthers \& Brouthers, 2001; Ghoshal \& Moran, 1996) and its awkward application to IB phenomena such as cultural differences. In other words, we could be in a position to contribute and improve TCE, but this requires us to first recognize its built-in country and culture biases.

Importantly, the cultural biases of the various theories we use, imported from organization theory, economics, strategy, or otherwise are not limited to TCE, as has been suggested by Hofstede (1983 and elaborated in his latter work) among others, and likely extend to home-grown IB theories such as the Uppsala model. Here was an opportunity for IB to take such biases to the next level, that is, not merely acknowledge them but engage in the ensuing theory development such as the refinement of theories to take stock of the said variations. Theoretical biases have not been only cultural in origin, but have their roots in varying institutional conditions, levels of economic development, market varieties, and the like, and particularly the combination of those cultural, institutional, economic, and social conditions, biases often exacerbated by the location choices made by researchers.

Similar logic applies to seeking contexts to test theories with an assumed universal and primarily Western focus, although complex relationships emerge from anthropological, sociological, and historical contingencies (Koch, Koch, Menon, \& Shenkar, 2016). These contingencies and the complex interactions are at the center of frequent shifts and trends in IB research. For instance, Cantwell (2009: 38) argues that "markets are now much less nationally segmented than they once were." However, in 2020 one can see a shift much like the 1970s when Rugman (1979) explained the 
increased salience of locations based on financial risk reduction motives. It will also be interesting to observe how research on evolutionary learning organizations shifts as international integration of MNE networks retracts and becomes more localized. With increased nationalism and emphasis on protectionist policies, research on transfer of knowledge and capabilities across different locations will be subject to many frictions.

Neglected geographies are not limited to underresearched countries. Place-based explanations and location dimension are contexts. Hence, the geographic unit of analysis is not only limited to the country level but also incorporates characteristics across within-country and across-country phenomena in a nonlinear fashion and use a relational perspective (e.g., Deng et al., 2020). Newly emerging studies that combine such nonlinear geographic contexts are applicable in interorganizational networks (Henderson \& Alderson, 2016) and political discontinuities across local and regional geopolitical contexts (Beugelsdijk \& Mudambi, 2013; Gluckler \& Doreian, 2016). For instance, subsidiaries of multinational corporations (MNCs) will have heterogeneity not only across countries (as expected and often portrayed), but also across regions within the same foreign markets, as in the Basque region versus the Catalan region in Spain. Such subnational locational heterogeneity has several implications for IB research. MNEs and SMEs approach subnational regions as part of their global network of activities, with many implications for technology transfer, economic development, knowledge, and learning as well as organizational challenges (e.g., Beugelsdijk \& Mudambi, 2013). There are several examples for spatial network positioning where developedmarket MNEs operating in emerging markets (e.g., McDermott \& Corredoira, 2010) and emergingmarket MNEs operating in developed markets (e.g., Hennart, 2009) interact with their contexts.

Emphasizing the interactions between the neglected actors in neglected locations will have at least two profound implications for extending the IB research. First, an integrated cycle of theorydriven and issue-driven research opens up the environment in what Buckley and Lessard (2005) refer to as a black box. Because the field is much more developed and stands on solid theoretical foundations, this open and eclectic approach will circumvent the "mix and match" issues of the early period (Buckley \& Lessard, 2005: 596) and allow us to focus on a new "core set of issues." Second, as
Buckley (2002: 370) put it, "the way forward is, paradoxically, to look back." New locations and new actors should remind us of the successful era when IB scholars not only import new paradigms but also allow us to ask the next "big question," whatever it may be. For instance, Buckley's fourth potentially big question centers on the challenges to global capitalism. Almost two decades after its introduction, neglected locations and firms have devised new means of financing, modes internationalization, and supply-chain reorchestration, unlike their developed market counterparts.

\section{CHALLENGES AND OPPORTUNITIES}

As suggested early on in this essay, our analysis is not intended to lament the state of a field that we believe has made remarkable strides over the half a century or so of its life, or to simply highlight voids in a literature that has turned deeper and more relevant over time. Rather, our aim is to identify and describe specific opportunities for making the field still stronger, or at the least start a healthy debate about the boundaries of the field and the ways to further increase its distinct intellectual contributions as compared to other fields of study.

The first opportunity is to carefully account for and generate meaning out of what has been accomplished in the field. This requires reflexivity, not just counting the occurrences (Rowlinson, Hassard, \& Decker, 2014). Otherwise, reporting the progress in the field would be reduced to record keeping where only a repository of ready-made data is produced. Several seminal quantitative review papers (e.g., Cantwell et al., 2014, 2016) as well as editorials (e.g., Cheng, Henisz, Roth, \& Swaminathan, 2009; Cantwell \& Brannen, 2011) provide a comprehensive account of extant literature. While these provide a good overview of the state of the field, there is an opportunity to quantify distinct bodies of research around the key discipline elements and methodologies that we use to investigate these elements (e.g., Aguinis, Ramani, \& Cascio, 2020; Deng et al., 2020; Nielsen et al., 2020). Quantitative review studies that shed light on the complex and comprehensive nature of theories, constructs, variables, contexts, and methodologies will help identify the discrete though increasingly interdependent assets in IB.

The second opportunity is to utilize the critical distinctions between interdisciplinary, multidisciplinary, and cross-disciplinary research (Cantwell \& Brannen, 2011, 2016). Going forward, mixing 
theories and constructs drawn from different disciplines and multidisciplinary approaches in which a series of separate contributions from different disciplines may occur independently or sequentially (Cheng, Birkinshaw, Lessard, \& Thomas, 2014) will augment the power of our explanations. While it is rewarding and fruitful to keep up with the changes in economic, social, political, and institutional elements in other fields (Buckley, 2002; Dunning, 1989), there are several challenges such as "perils of isolation" and loss of focus in an effort to "renew the interdisciplinary grounding of IB" (Cheng et al., 2009: 1073). We join the "call to arms" for pursuing more interdisciplinary research in IB and see the potential in the admonition of Cheng et al. (2009) in generating both new and revived interest to expand the frontier of IB knowledge.

The third opportunity is to ask the next big questions and to "open a dialogue with neighboring fields. This opportunity should remind the reader that during its successful era, international business researchers not only imported concepts and paradigms but they also exported them to neighboring areas" (Buckley, 2002: 370). We need to expand our pool of relevant disciplines as well as what we borrow from them, whether findings, theories, or methodologies. Speaking their language, challenging as it may be, will also enhance our exports to them and establish a dialogue that will be fruitful to both. We join Cheng et al. (2009) and assert that the basis of the "next big questions" in IB will be interdisciplinary, will utilize a combination or integration of ideas, and will separate the effort from multidisciplinary approaches of a sequential or independent nature. Furthermore, we project that there will be increased awareness around incorporating interdisciplinary work that is focused on both importing and exporting concepts and broadening IB's theory foundations by including more discipline-based positioning to overcome the structural constraints.

The fourth opportunity is developing and examining complex interactions among multilevel constructs in a systematic way. One of the salient contributions of this paper points out how such interactions can be identified and deployed, and we illustrate the benefits that can be had from so doing. Among the many benefits of looking at multiplicative and moderation effects across multiple levels, the potential to yield new theoretical insights is of particular interest (Andersson, Cuervo-Cazurra, \& Nielsen, 2014). Among multilevel analysis applications, the explanation of interaction effects goes beyond simple detection of statistically significant effects and must extend well-known predictions through grounded theoretical explanations (e.g., Lederman, 2010; Peterson, Arregle, \& Martin, 2012). When a field matures and increases in sophistication (Andersson et al., 2014), there will be strong contributions to the field of knowledge through empirical and theoretical operationalization of new moderators that are motivated by theory in foundational disciplines (e.g., Arikan \& Shenkar, 2013; Arikan et al., 2020). In this paper, we expanded on how the incorporation of the neglected elements can support the identification of new variables and constructs and contribute to current research frameworks and to the development of new paradigms and theories.

The fifth opportunity is to overcome data collection obstacles and address empirical difficulties in studies that encompass each of or a combination of the neglected elements. Given the evolving and complex nature of the IB field, the conventions posited entrench a dominant paradigm over time, resulting in a restricted set of methodological options being used (Nielsen et al., 2020). While these methodological restrictions may be due to researchers becoming comfortable with conventions, some might also be misconstrued as in the case of culture studies. For instance, in the context of "cultural distance," the "temptation was simply too big to pass up, especially as it yielded a single quantitative measure that could be incorporated into a regression equation, together with supposedly hard data variables" (Shenkar, 2012: 13). Two important criteria should guide how we should build on IB knowledge regarding neglected elements and soundly rule out alternative explanations: how replicable and trustworthy will the results be (Cuervo-Cazurra et al., 2016), and will theory explain the causality instead of ex post justification of data analysis and high-powered empirical "corrections" (Reeb, Sakakibara, \& Mahmood, 2012).

The strength of IB research depends on the "ability to identify the main theoretical mechanisms by which the dependent variable arises" (Reeb et al., 2012: 217). Given the complex nature of our contexts, going forward IB researchers will need to make a concerted effort to go beyond ruling out reverse causality. For instance, in testing cultural- and institutional-distance arguments developed in Shenkar (2012), Zaheer and colleagues (2012) and Luiz (2015) incorporate the complexity in cultural distance and identity formation in 
different countries to explain variance in cultural schisms, ethnicity, religion, etc. Similarly, Joshi and Lahiri (2015), Brouthers et al., (2016a, 2016b), and Harzing and Pudelko (2016) provide contributions in empirical testing of theory across different locations.

The sixth opportunity follows from the data obstacles discussed above. Going forward, particular attention should be paid to addressing three crucial biases that can potentially cripple empirical IB research: simultaneity bias, sample-selection bias, and rare-event bias when working with longitudinal datasets that cover neglected locations, environments, history, or complex interactions among them. Simultaneity (and endogeneity) bias impacts the reciprocal causation; sample-selection bias incorporates data points influenced by unknown (unobserved) factors (Arikan et al., 2020); and rare-event bias negatively impacts estimation accuracy not only because of too few observations (King \& Zeng, 2001), but also due to overlooking the importance of these few observations in a wider context (Arikan \& Shenkar, 2013).

\section{CONCLUSION AND IMPLICATIONS}

We argue that there are priority topics at the heart of IB and, while not claiming that these elements are the only ones that may have been neglected over time, we illustrate how future IB research needs to build on extant research and be cognizant of obstacles that may have limited their inclusion or emphasis so far. Our "call to action" recognizes the important contributions of IB scholars to date, reminds IB researchers that there is still much work to be done, and provides an impetus to pursue the mandates specified in this article. Our interest is on how the field has evolved instead of identifying specific papers that contributed to this evolution. Therefore, the focus is on the forest rather than the trees.

What is ahead for IB research? The reality of evolving economic systems and the new political period ahead of us necessitates the integration of more critical thinking about how causal relationships will take shape in regions and among countries and how this will impact other elements of our proposed framework. It seems undeniable that in 2020, global markets started going through a deep correction. Firms will most likely compete for both resources and markets in domestic and global markets, and borders between nations will matter. There are signals of societal and ideological shifts, political regime changes, as well as new fiscal and monetary arrangements to govern economic pressures. Increased competition between firms, nations, and trading blocks will likely increase the probability of political frictions and social unrest. The neglected locations, people, ideologies, histories, and firms will gain further importance; and the role of complex interactions between individuals, firms, societies, and nations will take center stage. Small versus large, young versus old, experienced versus inexperienced firms will be impacted by these changes and will have to compete in remote locations for securing resources and accessing markets (Arikan et al., 2020). For instance, the global pandemic underlined vulnerabilities in global supply chains, proved the importance of domestic production capabilities, and emphasized the significance of domestic markets. Increasing "nationalist populism" across the globe, which we refer to as a state where the majority in a society isolate and defend their own national interests to the detriment of other nations' interests, will make IB more salient, not less in the next few decades. Furthermore, nearly all countries will rearrange their infrastructures to build, grow, and secure themselves. These rearrangements will require extensive geopolitical positioning, and we project an increased attention to IB domains.

Our emphasis on the complexities of IB research has several implications. Capturing complexity is challenging, which may explain why it is not often done. Yet it is too important to leave out or sacrifice for the sake of parsimony. We assert that there should be a balance between the two, but hold that the pendulum has moved too much to the parsimony side. In the name of parsimony, we lose rich contexts and complexity, which is both "a blessing and a curse" in our field (Sullivan, 1998a, 1998b). The implications of this paper for empirical studies in IB are as follows. Most of the constructs that we use as control variables to account for alternative explanations from other disciplines do in fact endogenously influence most of the commonly used explanatory variables in IB research. Conversely, some of these constructs from other disciplines are exogenous to firm choices and outcomes in IB but can serve as a treatment in natural experiments. However, this approach requires a deep understanding of disciplinary knowledge in the context of interdisciplinary inquiry. On this point, we echo the Cheng et al. (2014) editorial in JIBS. 
In this paper, we have illustrated that the neglected elements are not missing from our research, but that these underemphasized elements have been treated as exogenous factors embedded in the macroenvironment of the firms that engage in IB. Instead, we propose a concerted effort to endogenize the theories and concepts that are embedded in the foundational disciplines. We suggest new approaches that will present opportunities for integrating multilevel studies that connect individuals, teams, groups, firms, subsidiaries, and collaborative organizational forms. Therein lie many sources of heterogeneity and frictions that will enrich future IB research.

\section{REFERENCES}

Abel, R. 1974. A comparative theory of dispute institutions in society. Law \& Society Review, 8(2): 217-347.

Aguinis, H., Ramani, R. S., \& Cascio, W. F. 2020. Methodological practices in international business research: An after-action review of challenges and solutions. Journal of International Business Studies, 51(9): 1593-1608.

Alcácer, J., Cantwell, J., \& Piscitello, L. 2016. Internationalization in the information age: A new era for places, firms, and international business networks? Journal of International Business Studies, 47(5): 499-512.

Alvarez, S., \& Rangan, S. 2019. The rise of nationalism (redux): An opportunity for reflection and research. Academy of Management Review, 44(4): 719-723.

Andersson, U., Cuervo-Cazurra, A., \& Nielsen, B. 2014. From the editors: Explaining interaction effects within and across levels of analysis. Journal of International Business Studies, 45(9): 1063-1071.

Ansell, B., \& Lindvall, J. 2013. The political origins of primary education systems: Ideology, institutions, and interdenominational conflict in an era of nation-building. American Political Science Review, 107(3): 505-522.

Arikan, I., Arikan, A., \& Shenkar, O. 2020. Nation-dyadic history and cross-border corporate deals: Role of conflict, trade, generational distance, and professional education. Strategic Management Journal, 41(3): 422-466.

Arikan, I., \& Shenkar, O. 2013. National animosity and crossborder alliances. Academy of Management Journal, 56(6): 1516-1544.

Autio, E. 2005. Creative tension: The significance of Ben Oviatt's and Patricia McDougall's article "toward a theory of international new ventures." Journal of International Business Studies, 36(1): 9-19.

Balabanis, G., Diamantopoulos, A., Mueller, E. D., \& Melewar, T. C. 2001. The impact of nationalism, patriotism and internationalism on consumer ethnocentric tendencies. Journal of International Business Studies, 32(1): 157-175.

Banalieva, E., \& Eddleston, K. 2011. Home-region focus and performance of family firms: The role of family vs. non-family leaders. Journal of International Business Studies, 42(8): 1060-1072.

Beck, T., Demirguc-Kunt, A., \& Levine, R. 2005. SMEs, growth, and poverty: Cross-country evidence. Journal of Economic Growth, 10(3): 199-229.

Berger, P. L., \& Luckmann, T. 1967. The social construction of reality: $A$ treatise in the sociology of knowledge. New York: Anchor Books.

\section{NOTES}

${ }^{1}$ After World War II, the Allied occupation authorities ordered the zaibatsu dissolved. During the re-industrialization of Japan, they emerged as keiretsu, which was a horizontal linkage between affiliated firms (through cross shareholdings and interlocking directorates) that were organized around a bank (Lincoln, Gerlach, \& Ahmadjian, 1996). These linkages had a strong impact on firms' performance (Wan, Yiu, Hoskisson, \& Kim, 2008), as well their international expansion patterns (Collinson \& Rugman, 2008; Rugman \& Verbeke, 2004).

Beugelsdijk, S., \& Mudambi, R. 2013. MNEs as bordercrossing multi-location enterprises. Journal of International Business Studies, 44(5): 413-426.

Biggart, N. W., \& Hamilton, G. C. 1992. On the limits of a firmbased theory to explain business networks: The Western bias of neoclassical economics. In N. Nohria, \& R. G. Eccless (Eds.), Networks and organizations: Structure, form, and action: 471-490. Brighton: Harvard Business School Press.

Biggs, T., Vijaya, R., \& Shah, M. 1998. The determinants of enterprise growth in Sub-Saharan Africa: Evidence from the regional program on enterprise development. World Bank $R P E D$, Discussion Paper, 103.

Birkinshaw, J., Bouquet, C., \& Ambos, T. C. 2007. Managing executive attention in the global company. MIT Sloan Management Review, 48(4): 39-45.

Boddewyn, J., \& lyer, G. 1999. International business research: Beyond déjà vu. Management International Review, 39(2): 161-184.

Boellis, A., Mariotti, S., Minichilli, A., \& Piscitello, L. 2016. Family involvement and firms' establishment mode choice in foreign markets. Journal of International Business Studies, 47(8): 929-950.

Boisot, M., \& Child, J. 1996. From fiefs to clans and network capitalism: Explaining China's emerging economic order. Administrative Science Quarterly, 41(4): 600-628.

Bouquet, C., Morrison, A., \& Birkinshaw, J. 2009. International attention and multinational enterprise performance. Journal of International Business Studies, 40(1): 108-131.

Bourdieu, P. 1984. Distinction. Cambridge: Harvard University Press.

Boyacigiller, N. A., \& Adler, N. J. 1991. The parochial dinosaur: Organizational science in a global context. Academy of Management Review, 16(2): 262-290.

Branzei, O., \& Abdelnour, S. 2010. Another day, another dollar: Enterprise resilience under terrorism in developing countries. Journal of International Business Studies, 41(5): 804-825.

Brouthers, K., \& Brouthers, L. 2001. Explaining the national cultural distance paradox. Journal of International Business Studies, 32(1): 177-189.

Brouthers, K., Geisser, K., \& Rothlauf, F. 2016a. Explaining the internationalization of i-business firms. Journal of International Business Studies, 47(5): 513-534.

Brouthers, L., Marshall, V., \& Keig, D. 2016b. Solving the singlecountry sample problem in cultural distance studies. Journal of International Business Studies, 47(1): 471-479.

Brown, C., Medoff, J., \& Hamilton, J. 1990. Employers: Large and small. Cambridge: Harvard University Press. 
Brubaker, R. 1996. Nationalism reframed: Nationhood and the national question in the new Europe. Cambridge: Cambridge University Press.

Brubaker, R. 2004. Ethnicity without groups. Cambridge: Harvard University Press.

Buckley, P. 2002. Is the international business research agenda running out of steam? Journal of International Business Studies, 33(2): 365-373.

Buckley, P., \& Casson, M. 1998. Models of the multinational enterprise. Journal of International Business Studies, 29(1): 21-44.

Buckley, P., \& Lessard, D. 2005. Regaining the edge for international business research. Journal of International Business Studies, 36(6): 595-599.

Buckley, P. J., Doh, J. P., \& Benischke, M. H. 2017. Towards a renaissance in international business research? Big questions, grand challenges and the future of IB scholarship. Journal of International Business Studies, 48(9): 1045-1064.

Cantwell, J. 2009. Location and the multinational enterprise. Journal of International Business Studies, 40(1): 35-41.

Cantwell, J., \& Brannen, M. 2011. Positioning JIBS as an interdisciplinary journal. Journal of International Business Studies, 42(1): 1-9.

Cantwell, J., Dunning, J., \& Lundan, S. 2010. An evolutionary approach to understanding international business activity: The co-evolution of MNEs and the institutional environment. Journal of International Business Studies, 41(4): 567-586.

Cantwell, J., Piepenbrink, A., \& Shukla, P. 2014. Editorial: Assessing the impact of JIBS as an interdisciplinary journal: A network approach. Journal of International Business Studies, 45(7): 787-799.

Cantwell, J., Piepenbrink, A., Shukla, P., \& Vo, A. 2016. The changing landscape of JIBS authorship. Journal of International Business Studies, 47(7): 749-777.

Cantwell, J. A. 1995. The globalization of technology: What remains of the product cycle model? Cambridge Journal of Economics, 19(1): 155-174.

Cantwell, J., \& Brannen, M. 2016. The changing nature of the international business field and the progress of JIBS. Journal of International Business Studies, 47(9): 1023-1031.

Cantwell, J. A., \& Mudambi, R. 2005. MNE competencecreating subsidiary mandates. Strategic Management Journal, 26(12): 1109-1128.

Carrel, P. 2017. Germany's 2016 trade surplus sets record, may fuel U.S. tensions. Reuters, February 9. https://www.reuters. com/article/us-germany-economy-trade/germanys-2016trade-surplus-sets-record-may-fuel-u-s-tensionsidUSKBN1501BO.

Caves, R. 1998. Research on international business: Problems and prospects. Journal of International Business Studies, 29(1): 5-19.

Chandler, A. D. 1977. The visible hand: Managerial revolution in American business. Cambridge: Harvard University Press.

Cheng, J., Birkinshaw, J., Lessard, D., \& Thomas, D. 2014. Advancing interdisciplinary research: Insights from the JIBS special issue. Journal of International Business Studies, 45(6): 643-648.

Cheng, I. L., Henisz, W., Roth, K., \& Swaminathan, A. 2009. Advancing interdisciplinary research in the field of international business. Prospects, issues, and challenges. Journal of International Business Studies, 40(7): 1070-1074.

Child, J., \& Tse, D. 2001. China's transition and its implications for international business. Journal of International Business Studies, 32(1): 5-21.

Clairmonte, F., \& Cavanagh, J. H. 1988. World commodities trade: Changing role of giant trading companies. Economic and Political Weekly, 23(42): 2153-2157.

Cohen-Scali, V. 2003. The influence of family, social, and work socialization on the construction of the professional identity of young adults. Journal of Career Development, 29(4): 237-249.
Collier, P., \& Goderis, B. 2009. Structural policies for shockprone developing countries. Oxford Economic Papers, 61(4): 703-726.

Collinson, S., \& Rugman, A. M. 2008. The regional nature of Japanese multinational business. Journal of International Business Studies, 39(2): 215-230.

Cuervo-Cazurra, A., Andersson, U., Brannen, M., Nielsen, B., \& Reuber, A. 2016. Can I trust your findings? Ruling out alternative explanations in international business research. Journal of International Business Studies, 47(8): 881-897.

Cuervo-Cazurra, A., Caligiuri, P., Andersson, U., \& Brannen, M. 2013. How to write articles that are relevant to practice. Journal of International Business Studies, 44(4): 285-289.

Cyert, R. M., \& March, J. G. 1963. A behavioral theory of the firm. Hoboken: Prentice Hall/Pearson Education.

Dai, L., Eden, L., \& Beamish, P. 2013. Place, space, and geographical exposure: Foreign subsidiary survival in conflict zones. Journal of International Business Studies, 44(6): 554-578.

Darendeli, I. S., \& Hill, T. 2016. Uncovering the complex relationships between political risk and MNE firm legitimacy: Insights from Libya. Journal of International Business Studies, 47(1): 68-92.

Deng, P., Delios, A., \& Peng, M. W. 2020. A geographical relational perspective on the internationalization of emerging market firms. Journal of International Business Studies, 51(12): $50-71$.

Di Martino, P., \& Vasta, M. 2010. Companies' insolvency and "the nature of the firm" in Italy, 1920s-70s. Economic History Review, 63(1): 137-164.

DiMaggio, P. 1987. Classification in art. American Sociological Review, 52(4): 440-455.

Doob, L. W. 1964. Patriotism and nationalism: Their psychological foundations. New Haven: Yale University Press.

Doz, Y. 2011. Qualitative research for international business. Journal of International Business Studies, 42(5): 582-590.

Druckman, D. 1994. Nationalism, patriotism, and group loyalty: A social psychological perspective. Mershon International Studies Review, 38(1): 43-68.

Dunne, T., Roberts, J., \& Samuelson, L. 1989. Growth and failure of U.S. manufacturing plants. Quarterly Journal of Economics, 104(4): 671-698.

Dunning, J. H. 1970. Studies in international investment. London: Allen \& Unwin.

Dunning, J. H. 1989. The study of international business: A plea for a more interdisciplinary approach. Journal of International Business Studies, 20(3): 411-436.

Dunning, J. H. 1996. The geographical sources of competitiveness of firms: Some results from a new survey. Transnational Corporations, 5(3): 1-30.

Dunning, J. H. 2009. Location and the multinational enterprise: John Dunning's thoughts on receiving the Journal of International Business Studies, 2008 Decade Award. Journal of International Business Studies, 40(1): 20-34.

Egan, M. 2020. Trump orders Chevron to halt oil production in Venezuela. CNN Business, April 22. https://www.cnn.com/ 2020/04/22/business/chevron-venezuela-oil-trump/index. html.

Faccio, M., Lang, L., \& Young, L. 2001. Dividends and expropriation. American Economic Review, 91(1): 54-78.

Farren, D., \& Makhija, A. K. 2021. The middle market is stressed, but resilient. Harvard Business Review, March, 8.

Foster, G. M. 1960. Culture and conquest: America's Spanish heritage. New York: Quadrangle Books.

Freeden, M. 2001. Ideology: Political aspects. In N. J. Smelser, \& P. B. Baltes (Eds.), International Encyclopedia of the social \& behavioral sciences: 7174-7177. Pergamon: Elsevier.

Gartzke, E., \& Rohner, D. 2011. The political economy of imperialism, decolonization and development. British Journal of Political Science, 41(3): 525-556. 
Geary, J., \& Aguzzoli, R. 2016. Miners, politics and institutional caryatids: Accounting for the transfer of HRM practices in the Brazilian multinational enterprise. Journal of International Business Studies, 47(8): 968-996.

Ghemawat, P. 2003. Semiglobalization and international business strategy. Journal of International Business Studies, 34(2): 138-152.

Ghoshal, S. 1987. Global strategy: An organizing framework. Strategic Management Journal, 8(5): 425-440.

Ghoshal, S., \& Moran, P. 1996. Bad for practice: A critique of the transaction cost theory. Academy of Management Review, 21(1): 13-47.

Gluckler, J., \& Doreian, P. 2016. Social network analysis and economic geography. Journal of Economic Geography, 16(6): 1123-1134.

Goodman, P. S., \& Bubola, E. 2019. The Chinese roots of Italy's far-right rage. New York Times, December, 5. https://www. nytimes.com/2019/12/05/business/italy-china-far-right.html.

Gootman, M., Sio, B., Shenkar, O., \& Stewart, T. A. 2016. Accelerating exports in the middle market: Global opportunities for U.S. firms and metro areas. The National Center for the Middle Market, Metropolitan Policy Program at Brookings: https://brookings.edu/wp-content/uploads/2016/06/ acceleratingexportsinthemiddlemarkets.pdf.

Gowa, J. 1994. Allies, adversaries, and international trade. Princeton: Princeton University Press.

Gowa, J., \& Mansfield, E. D. 1993. Power politics and international trade. American Political Science Review, 87(2): 408-420.

Guriev, S., \& Zhuravskaya, E. 2009. (Un)happiness in transition. Journal of Economic Perspectives, 23(2): 143-168.

Hafner-Burton, E., Kahler, M., \& Montgomery, A. 2009. Network analysis for international relations. International Organization, 63(3): 559-592.

Halbwachs M. 1950/1980. The collective memory. New York: Harper and Row.

Hannan, M. T., \& Freeman, J. 1986. Where do organizational forms come from? Sociological Forum, 1(1): 50-72.

Hannan, M. T., \& Freeman, J. 1989. Organizational ecology. Cambridge: Harvard University Press.

Harding, H. 1982. From China, with disdain: New trends in the study of China. Asian Survey, 22(10): 934-958.

Harmeling, C., Magnusson, P., \& Singh, N. 2015. Beyond anger: A deeper look at consumer animosity. Journal of International Business Studies, 46(6): 676-693.

Harzing, A., \& Pudelko, M. 2016. Do we need to distance ourselves from the distance concept? Why home and host country context might matter more than (cultural) distance. Management International Review, 56(1): 1-34.

$\mathrm{He}$, Y. 2014. Identity politics and foreign policy: Taiwan's relations with China and Japan, 1895-2012. Political Science Quarterly, 129(3): 469-500.

Henderson, W. D., \& Alderson, A. S. 2016. The changing economic geography of large U.S. law firms. Journal of Economic Geography, 16(6): 1235-1257.

Hennart, J. 2009. Down with MNE-centric theories! Market entry and expansion as the bundling of MNE and local assets. Journal of International Business Studies, 40(9): 1432-1591.

Hetherington, P. 1993. Explaining the crisis of capitalism in Kenya. African Affairs, 92(366): 89-103.

Hofstede, G. 1983. The cultural relativity of organizational practices and theories. Journal of International Business Studies, 14(2): 75-89.

Hoover, G. 1942. Government intervention in the post-war economy. American Journal of Economics and Sociology, 1(4): 381-402.

Hout, T., \& Michael, D. 2014. A Chinese approach to management. Harvard Business Review, 92: 1-6.

Huy, Q. 2011. How middle managers' group-focus emotions and societal identities influence strategy implementation. Strategic Management Journal, 32(13): 1387-1410.
Ingram, P., \& Torfason, M. 2010. Organizing the in-between: The population dynamics of network-weaving organizations in the global interstate network. Administrative Science Quarterly, 55(4): 577-605.

Jackson, G., \& Deeg, R. 2008. Comparing capitalisms: Understanding institutional diversity and its implications for international business. Journal of International Business Studies, 39(4): 540-561.

Jeong, Y., \& Weiner, R. J. 2012. Who bribes? Evidence from the United Nations' oil-for-food program. Strategic Management Journal, 33(12): 1363-1383.

Johanson, J., \& Vahlne, J. 1977. The internationalization process of the firm: A model of knowledge development and increasing foreign market commitments. Journal of International Business Studies, 8(1): 23-32.

Jones, G. 2002. Merchants to multinationals: British trading companies in the nineteenth and twentieth centuries. Oxford: Oxford University Press.

Jones, G., \& Khanna, T. 2006. Bringing history (back) into international business. Journal of International Business Studies, 37(4): 453-468.

Joshi, A., \& Lahiri, N. 2015. Language friction and partner selection in cross-border R\&D alliance formation. Journal of International Business Studies, 46(2): 123-152.

Judge, W. Q., Fainshmidt, S., \& Brown, J. L. 2014. Which model of capitalism best delivers both wealth and equality? Journal of International Business Studies, 45(4): 363-386.

Kahnweiler, W., \& Thompson, M. 2000. Levels of desired, actual, and perceived control of employee involvement in decision-making: An empirical investigation. Journal of Business and Psychology, 14(3): 407-427.

Kaplan, S. 1973. Cognitive maps in perception and thoughts. In R. M. Downs, \& D. Stea (Eds.), Cognitive mapping: Images of special environment. Location: Routledge.

Karasawa, M. 2002. Patriotism, nationalism, and internationalism among Japanese citizens: An etic-emic approach. Political Psychology, 23(4): 645-666.

Karnik, M., \& Balachandran, M. 2016. After nearly a decade and an ill-fated takeover, Tata Steel decides it can't survive in the UK. Quartz India, March 30. https://qz.com/india/650551/ tata-steels-desire-to-get-rid-of-its-uk-business-shows-howunlucky-its-corus-takeover-was/.

Keohane, R. O. 1984. After hegemony: Cooperation and discord in the world political economy. Princeton: Princeton University Press.

King, G., \& Zeng, L. 2001. Explaining rare events in international relations. International Organization, 55(3): 693-715.

Kirchhoff, B. A., \& Kirchhoff, J. J. 1987. Family contributions to productivity and profitability in small business. Journal of Small Business Management, 25(4): 25-31.

Koch, P., Koch, B., Menon, T., \& Shenkar, O. 2016. Cultural friction in leadership beliefs and foreign-invested enterprise survival. Journal of International Business Studies, 47(4): 453-470.

Krasner, S. D. 1978. Defending the national interest: Raw materials investments and U.S. foreign policy. Princeton: Princeton University Press.

Kreijger, G. 2017. Germany first: The return of mercantilism. Handelsblatt, June 2. https://www.handelsblatt.com/english/ promoting-trade-germany-first-the-return-of-mercantilism/ 23570190.html?ticket=ST-3009738-igGLvXiFn3uaJEOzgpocap5.

Lasok, K. 1981. Government intervention and state trading. Modern Law Review, 44(3): 249-269.

Lawler, J., Chen, S., Wu, P., Bae, J., \& Bai, B. 2011. Highperformance work systems in foreign subsidiaries of American multinationals: An institutional model. Journal of International Business Studies, 42(2): 202-220.

Lederman, D. 2010. An international multilevel analysis of product innovation. Journal of International Business Studies, 41(4): 606-619. 
Levine, D. 1974. Issues in the study of culture and politics: A view from Latin America. Publius, 4(2): 77-104.

Levy, D. 2008. Political contestation in global production networks. Academy of Management Review, 33(4): 943-963.

Li, C., Arikan, I., Shenkar, O., \& Arikan, A. 2020. The impact of country-dyadic military conflicts on market reaction to crossborder acquisitions. Journal of International Business Studies, 51(3): 299-325.

Li, M., Cui, L., \& Lu, J. 2014. Varieties in state capitalism: Outward FDI strategies of central and local state-owned enterprises from emerging economy countries. Journal of International Business Studies, 45(8): 980-1004.

Lincoln, J. R., Gerlach, M. L., \& Ahmadjian, C. L. 1996. Keiretsu networks and corporate performance in Japan. American Sociological Review, 61(1): 67-88.

Lizardo, O. 2006. How cultural tastes shape personal networks. American Sociological Review, 71(5): 778-807.

Lubinski, C. 2011. Path dependency and governance in German family firms. Business History Review, 85(4): 699-724.

Luiz, J. 2015. The impact of ethno-linguistic fractionalization on cultural measures: Dynamics, endogeneity and modernization. Journal of International Business Studies, 46(9): 1080-1098.

Mariotti, S., \& Marzano, R. 2019. Varieties of capitalism and the internationalization of state-owned enterprises. Journal of International Business Studies, 50(5): 669-691.

Max, D. T. 2018. The Chinese workers who assemble designer bags in Tuscany. The New Yorker, April 9. https://www. newyorker.com/magazine/2018/04/16/the-chinese-workerswho-assemble-designer-bags-in-tuscany.

McDermott, G. A., \& Corredoira, R. A. 2010. Network composition, collaborative ties, and upgrading in emerging-market firms: Lessons from the Argentine autoparts sector. Journal of International Business Studies, 41(2): 308-329.

McMinnon, R. I. 1997. Market-preserving fiscal federalism in the American monetary union. In M. I. Blejer, \& T. Ter-Minassian (Eds.), Macroeconomic dimensions of public finance: 73-93. Location: Routledge.

McMullen, J., \& Shepherd, D. 2006. Entrepreneurial action and the role of uncertainty in the theory of the entrepreneur. Academy of Management Review, 31(1): 132-152.

Merton, R. K. 1996. On social structure and science. Chicago: University of Chicago Press.

Meyer, K. E., Li, C., \& Schotter, A. P. 2020. Managing the MNE subsidiary: Advancing a multi-level and dynamic research agenda. Journal of International Business Studies, 51(4): 538-576.

Meyer, K., \& Peng, M. 2016. Theoretical foundations of emerging economy business research. Journal of International Business Studies, 47(1): 3-22.

Morck, R., \& Yeung, B. 2007. History in perspective: Comment on Jones and Khanna "Bringing history (back) into international business." Journal of International Business Studies, 38(2): 357-360.

Mudambi, R., \& Zahra, S. 2007. The survival of international new ventures. Journal of International Business Studies, 38(2): 333-352.

Ndegwa, S. 1997. Citizenship and ethnicity: An examination of two transition moments in Kenyan politics. American Political Science Review, 91(3): 599-616.

Neelankavil, J., Mathur, A., \& Zhang, Y. 2000. Determinants of managerial performance: A cross-cultural comparison of the perceptions of middle-level managers in four countries. Journal of International Business Studies, 31(1): 121-140.

Nielsen, B. B., Welch, C., Chidlow, A., Miller, S. R., Aguzzoli, R., Gardner, E., Karafyllia, M., \& Pegoraro, D. 2020. Fifty years of methodological trends in JIBS: Why future IB research needs more triangulation. Journal of International Business Studies, 51(9): 1478-1499.
Nohria, N., \& Ghoshal, S. 1997. The differentiated network: Organizing multinational corporations for value creation. San Francisco: Jossey-Bass.

North, D. C. 1990. Institutions, institutional change and economic performance. Cambridge: Cambridge University Press.

North, D., \& Weingast, B. 1989. Constitutions and commitment: The evolution of institutions governing public choice in seventeenth-century England. Journal of Economic History, 49(4): 803-832.

OECD 2019. OECD SME and entrepreneurship outlook 2019. Paris: OECD Publishing. https://doi.org/10.1787/34907e9cen.

Oettl, A., \& Agrawal, A. 2008. International labor mobility and knowledge flow externalities. Journal of International Business Studies, 39(8): 1242-1260.

Ognibene, S. 2020. From zero to hero: Italy's Chinese help beat coronavirus. Reuters, March 31. https://www.reuters.com/ article/us-health-coronavirus-italy-chinese/from-zero-to-heroitalys-chinese-help-beat-coronavirus-idUSKBN21I3I8.

Ornston, D., \& Vail, M. 2016. The developmental state in developed societies: Power, partnership, and divergent patterns of intervention in France and Finland. Comparative Politics, 49(1): 1-21.

PBS. 2016. Meet Zari, Sesame Street's new female Afghan muppet. April 12. https://www.pbs.org/newshour/arts/meetzari-sesame-streets-new-female-afghan-puppet.

Peschanski, V. 1985. Middle managers in contemporary capitalism. Acta Sociologica, 28(3): 243-255.

Peterson, M., Arregle, I., \& Martin, X. 2012. Multilevel models in international business research. Journal of International Business Studies, 43(5): 451-457.

Pfeifer, S. \& Pickard, J. 2019. UK government intervenes in Cobham's 4 billion pound takeover. Financial Times, September 18. https://www.ft.com/content/cb6f9b92-d9db-11e98f9b-77216ebe1f17.

Polanyi, K. 1944. The great transformation: The political and economic origins of our time. Little Rock: Rhinehart and Company.

Polanyi, K. 2001. The great transformation. Boston: Beacon Press.

Punnett, B. J., \& Shenkar, O. 1994. Broadening research horizons internationally. International Studies of Management \& Organization, 24(1/2): 3-8.

Redding, G. 2005. The thick description and comparison of societal systems of capitalism. Journal of International Business Studies, 36(2): 123-155.

Reeb, D., Sakakibara, M., \& Mahmood, I. 2012. From the editors: Endogeneity in international business research. Journal of International Business Studies, 43(3): 211-218.

Ricardo, D. 1817. On the principles of political economy and taxation (John Murray, London). In P. Sraffa (Ed.), The works and correspondence of David Ricardo: 1951, vol. 1. Cambridge: Cambridge University Press.

Riker, W. H. 1964. Federalism: Origin, operations, and significance. Boston: Little Brown.

Ronen, S., \& Shenkar, O. 2013. Mapping world cultures: Cluster formation, sources and implications. Journal of International Business Studies, 44(9): 867-897.

Ronen, S., \& Shenkar, O. 2017. Navigating global business: A cultural compass. Cambridge: Cambridge University Press.

Rowlinson, M., Hassard, J., \& Decker, S. 2014. Research strategies for organizational history: A dialogue between historical theory and organizational theory. Academy of Management Review, 39(3): 250-274.

Roy, T. 2014. Trading firms in colonial India. Business History Review, 88(1): 9-42.

Ruef, M. 2000. The emergence of organizational forms: A community ecology approach. American Journal of Sociology, 106(3): 658-714.

Rugman, A. M. 1979. International diversification and the multinational enterprise. Lexington: DC Heath. 
Rugman, A. M., \& Verbeke, A. 2001. Subsidiary-specific advantages in multinational enterprises. Strategic Management Journal, 22(3): 237-250.

Rugman, A. M., \& Verbeke, A. 2004. A perspective on regional and global strategies of multinational enterprises. Journal of International Business Studies, 35(1): 3-18.

Rugman, A. M., \& Verbeke, A. 2008. Location, competitiveness and the multinational enterprise. In A. M. Rugman (Ed.), Oxford handbook of international business. Oxford: Oxford University Press.

Saez, E., \& Zucman, G. 2020. This crisis calls for massive government intervention: Here is how to do it. The Guardian, March 17. https://www.theguardian.com/commentisfree/ 2020/mar/17/governments-crisis-coronavirus-business.

Sambharya, R. 1996. Foreign experience of top management teams and international diversification strategies of U.S. multinational corporations. Strategic Management Journal, 17(9): 739-746.

Sarasvathy, S. D. 2001. Causation and effectuation: Toward a theoretical shift from economic inevitability to entrepreneurial contingency. Academy of Management Review, 26(2): 243-288.

Schmiegelow, H., \& Schmiegelow, M. 1975. The new mercantilism in international relations: The case of France's external monetary policy. International Organization, 29(2): 367-391.

Schumpeter, J. 1950. Capitalism, socialism, and democracy (3rd ed.). New York: Harper \& Row Publishers Inc.

Shane, S. 2000. Prior knowledge and the discovery of entrepreneurial opportunities. Organization Science, 11(4): 448-469.

Shenkar, O. 1994. The People's Republic of China: Raising the bamboo screen through international management research. International Studies of Management \& Organization, 24(1/2): 9-34.

Shenkar, O. 2001. Cultural distance revisited: Towards a more rigorous conceptualization and measurement of cultural differences. Journal of International Business Studies, 32(3): 519-535.

Shenkar, O. 2004. One more time: International business in a global economy. Journal of International Business Studies, 35(2): 161-171.

Shenkar, O. 2012. Beyond cultural distance: Switching to a friction lens in the study of cultural differences. Journal of International Business Studies, 43(1): 12-17.

Shenkar, O., \& Arikan, I. 2009. Business as international politics: Drawing insights from nation-state to interfirm alliances. Business and Politics, 11(4): 1-32.

Shenkar, O., Luo, Y., \& Yeheskel, O. 2008. From "distance" to "friction": Substituting metaphors and redirecting intercultural research. Academy of Management Review, 33(4): 905-923.

Sibley, C., \& Osborne, D. 2016. Ideology and post-colonial society. Political Psychology, 37(S1): 115-161.

Sullivan, D. 1998a. The ontology of international business: A comment on international business: An emerging vision. Journal of International Business Studies, 29(4): 877-885.

Sullivan, D. 1998b. Cognitive tendencies in international business research: Implications of a "narrow vision." Journal of International Business Studies, 29(4): 837-862.

Sullivan, J., Fried, A., \& Dietz, M. 1992. Patriotism, politics, and the presidential election of 1988. American Journal of Political Science, 36(1): 200-234.

Suzuki, H. 2013. Death and dying in contemporary Japan. London: Routledge.

Tenopir, C., Dalton, E., Fish, A., Christian, L., Jones, M., \& Smith, M. 2016. What motivates authors of scholarly articles? The importance of journal attributes and potential audience on publication choice. Publications, 4(3): 1-22.

Thomas, A., Shenkar, O., \& Clarke, L. 1994. The globalization of our mental maps: Evaluating the geographic scope of JIBS coverage. Journal of International Business Studies, 25(4): 675-686.
Thompson, E. P. 1971. The moral economy of the English crowd in the eighteenth century. Past and Present, 50: 76-136.

Triadafilopoulos, T. 2010. Global norms, domestic institutions and the transformation of immigration policy in Canada and the U.S. Review of International Studies, 36(1): 169-193.

Tsui-Auch, L., \& Möllering, G. 2010. Wary managers: Unfavorable environments, perceived vulnerability, and the development of trust in foreign enterprises in China. Journal of International Business Studies, 41(6): 1016-1035.

Tuathail, G. 1997. At the end of geopolitics? Reflections on a plural problematic at the century's end. Alternatives: Global, Local, Political, 22(1): 35-55.

Vardi, Y., \& Hammer, T. 1977. Intraorganizational mobility and career perceptions among rank and file employees in different technologies. Academy of Management Journal, 20(4): 622-634.

Veblen, T. 1898. Why is economics not an evolutionary science? Quarterly Journal of Economics, 12(4): 373-397.

Vernon, R. 1966. International investment and international trade in the product cycle. Quarterly Journal of Economics, 80(2): 190-207.

Walder, A., Isaacson, A., \& Lu, Q. 2015. After state socialism: The political origins of transitional recessions. American Sociological Review, 80(2): 444-468.

Wan, W. P., Yiu, D. W., Hoskisson, R. E., \& Kim, H. 2008. The performance implications of relationship banking during macroeconomic expansion and contraction: A study of Japanese banks' social relationships and overseas expansion. Journal of International Business Studies, 39(3): 406-427.

Wang, A. B. 2017. For decades, no one spoke of Taiwan's hidden massacre. A new generation is breaking the silence. Washington Post, February 28. https://www.washingtonpost. com/news/worldviews/wp/2017/02/28/for-decades-no-onespoke-of-taiwans-hidden-massacre-a-new-generation-isbreaking-the-silence/.

Washbrook, D. 2010. Merchants, markets, and commerce in early modern South India. Journal of the Economic and Social History of the Orient, 53(1/2): 266-289.

Weber, M. 1961. General economic history. Springfield: Collier Books.

Weingast, B. 1995. The economic role of political institutions: Market-preserving federalism and economic development. Journal of Law, Economics, \& Organization, 11(1): 1-31.

Welle, D. 2020. Germany posts record-breaking budget surplus. January 13. https://www.dw.com/en/germany-posts-recordbreaking-budget-surplus/a-51991140.

Westwood, S., \& Diamond, J. 2020. Trump announces face mask manufacturing deal with $3 \mathrm{M}$ after contentious negotiations. CNN Politics, April 7. https://www.cnn.com/2020/04/ 06/politics/trump-3m-defense-production-act-masks/index. html.

Whyte, M. 1973. Bureaucracy and modernization in China: The Maoist critique. American Sociological Review, 38(2): 149-163.

Wimmer, A., \& Feinstein, Y. 2010. The rise of the nation-state across the world, 1816 to 2001. American Sociological Review, 75(5): 764-790.

Witt, M. 2008. Crossvergence 10 years on: Impact and further potential. Journal of International Business Studies, 39(1): 47-52.

Witt, M. A., \& Jackson, G. 2016. Varieties of capitalism and institutional comparative advantage: A test and reinterpretation. Journal of International Business Studies, 47(7): 778-806.

Yip, G. S. 1992. Total global strategy: Managing for worldwide competitive advantage. Hoboken: Prentice Hall.

Zaheer, S., Schomaker, M., \& Nachum, L. 2012. Distance without direction: Restoring credibility to a much-loved construct. Journal of International Business Studies, 43(1): $18-27$.

Zald, M. N. 1993. Organization studies as a scientific and humanistic enterprise: Towards a reconceptualization of the foundations of the field. Organization Studies, 4(4): 513-528. 
Zald, M. N. 1996. More fragmentation? Unfinished business in linking the social sciences and the humanities. Administrative Science Quarterly, 41(2): 251-261.

\section{ABOUT THE AUTHORS}

Ilgaz Arikan (PhD, The Ohio State University) His interdisciplinary work includes firm behavior in international, competitive, cooperative, conflicting, and historical contexts, and valuation and pricing in strategic factor markets. His work appeared in journals such as the AMJ, AMR, JIBS, MISQ, and SMJ, among others. He is an expert in the management and internationalization of authentic firms.

Oded Shenkar (PhD, Columbia University) holds the Ford Motor Company Chair in Global Business Management at The Ohio State University, where he is a Professor of Management and Human Resources and the Academic Director of the National Center for the Middle Market. He is also a member of the East Asian Studies Center and is a Fellow and Past Vice President of the Academy of International Business.

Publisher's Note Springer Nature remains neutral with regard to jurisdictional claims in published maps and institutional affiliations.

Accepted by Alain Verbeke, Editor-in-Chief, 12 July 2021. This article has been with the authors for two revisions. 